\title{
Primary production, physiological state and composition of phytoplankton in the Atlantic Sector of the Southern Ocean
}

\author{
A. U. Bracher ${ }^{1, *}$, B. M. A. Kroon ${ }^{1}$, M. I. Lucas ${ }^{2,3}$ \\ ${ }^{1}$ Alfred Wegener Institute for Polar and Marine Research, Postiach 120161, 27515 Bremerhaven, Germany \\ ${ }^{2}$ Zoology Department, University of Cape Town, Rondebosch 7700, South Africa \\ ${ }^{3}$ George Deacon Division, Southampton Oceanography Centre, Empress Dock, Southampton SO14 3ZH, United Kingdom
}

\begin{abstract}
Phytoplankton species composition and primary production were studied in the Atlantic Sector of the Southern Ocean in early austral summer 1.995/1996. Results from photosynthesis-irradiance experiments ( $P$ vs $E$ curves) were used to examine photosynthetic adaptation in this part of the ocean. The study area comprised 3 different provinces: the Antarctic Polar Front (APF), the Antarctic Circumpolar Current (ACC) beyond the influence of frontal systems, and the marginal ice zone (MIZ). Phytoplankton composition derived from HPLC data, $P^{\cdot}$ (maximum biomass-specific photosynthetic production rate) values and areal daily primary production (ADP) rates showed different features for these zones. The central core of the APF was dominated $(60 \%)$ by a bloom of large $(>20 \mu \mathrm{m})$ diatoms (Thalassiothrix spp., Pseudonitzschia cf. lineola and Chaetoceros spp.), equal values for $P{ }^{*}$ at the surface and $1 \%$ light depths and ADP rates exceeding $900 \mathrm{mg} \mathrm{C} \mathrm{m}^{-2} \mathrm{~d}^{-1}$. At the fringes of the APF core, phytoplankton were smaller, diatom abundance decreased and dinoflagellates, prymnesiophytes and chrysophytes became more importanl within the community. Chlorophyll a concentrations and ADP rates were low and comparable to values for the $\mathrm{AC}: \mathrm{C}$ outside the front: $<0.5 \mathrm{mg} \mathrm{m}^{-3}$ and $<300 \mathrm{mg} \mathrm{C}$ $\mathrm{m}^{-2} \mathrm{~d}^{-1}$ respectively. Beyond the frontal systems, $P^{*}$ in values from the $1 \%$ light depth were significantly higher than at the surface. There was also a bloom of large phytoplankton species within the MIZ, dominated in contrast by Phaeocystis spp.; this province was characterised by ADP rates of $558 \mathrm{mg} \mathrm{C} \mathrm{m}^{-2}$ $\mathrm{d}^{-1}$. Vertical mixing processes, temperature, silicate concentrations and zooplankton grazing seem to be the factors controlling production and growth of phytoplankton at this time.
\end{abstract}

KEY WORDS: Southern Ocean P Phytoplankton - Photosynthesis - Photoacclimation - Pigment composition

\section{INTRODUCTION}

A current objective of biological oceanography is to quantify the mean and variance of phytoplankton biomass and production on basin-wide and global scales (Bidigare et al. 1992). Early productivity studies in the Southern Ocean were carried out in areas with localised high biomass and production, leading to erroneously high estimates of total productivity for the entire Southern Ocean (El-Sayed 1984, Jacques 1989). Today, it is clear that productivity in the Southern

·E-mail: abracher@awi-bremerhaven.de
Ocean is highly variable (Sullivan et al. 1993, Arrigo et al. 1998, Bathmann et al. 1998). However, compared to other regions maximum phytoplankton growth rates are generally low $\left(<0.6 \mathrm{~d}^{-1}\right)$ due to the low temperature (Sakshaug \& Slagstad 1991).

Despite high macronutrient concentrations, the main body of the Antarctic Circumpolar Current (ACC) is typified by chlorophyll a (chl a) concentrations of $<0.3 \mathrm{mg} \mathrm{m}^{-3}$ over a deep mixed layer and correspondingly low productivity by nano- and picoplankton (e.g. Jacques 1989) characteristic of an HNLC (high-nutrients-low-chlorophyll) ocean (Chisholm \& Morel 1991) Low surface temperatures, weak density stratification, little summertime surface irradiance, low iron concen- 
trations, strong wind stress and high microzooplankton grazing pressures all contribute to the low biomass and productivity typical of the ACC (Bathmann et al. 1998).

However, more productive regions do exist. The northern ACC is separated from the southern ACC by the Antarctic Polar Front (APF) located at about $50^{\circ} \mathrm{S}$ (Tréguer \& Jacques 1992, Orsi et al. 1995). Here, warmer water masses from mid-latitudes converge with colder ones from further south so that the APF is marked by meanders, mesoscale eddies and strong west-east zonal flow characterised by enhanced diatom dominated biomass and production (Comiso et al. 1990, Laubscher et al. 1993, Sullivan et al. 1993. Dafner \& Mordasova 1994, Bathmann et al. 1997a, Hense et al. 1998). One consequence of this is the sedimentation of silica-rich biogenic material giving rise to benthic opal concentrations which are higher than in any other ocean (Carmack 1977, DeMaster 1981, DeMaster et al. 1991, Mortlock et al. 1991, Pondaven et al. 1998).

The marginal ice zone (MIZ) region of the southern ACC is marked by seasonal sea ice formation and melt. As sea ice has a low salinity, one paradigm is that spring ice melt stabilises the water column, which, in conjunction with increasing light, stimulates the development of dense phytoplankton blooms in the upper stratified water column (Gran 1931, Sakshaug \& HolmHansen 1984, Smith \& NeIson 1986). While there is good evidence for this in many regions, it is not a universal finding. Recently, Pollard et al. (1995) noted that in the Bellingshausen Sea, the frontal dynamics of the Southern Polar Front exerted a stronger influence on phytoplankton distribution and productivity than did the retreating seasonal sea ice.

Many researchers have speculated on the factors responsible for causing differences in phytoplankton biomass and taxonomic distribution within the Southern Ocean. Light, temperature, trace nutrients, zooplankton grazing and physical mixing processes have all been commonly invoked over several decades as key factors governing phytoplankton biomass and productivity (e.g. Hart 1934, and reviews by HolmHansen et al. 1977, El-Sayed 1987, Bathmann et al. 1998). Rates of productivity and taxonomic groupings are also important determinants of biogeochemical processes within the Southern Ocean. Larger diatom blooms frequently characteristic of frontal systems are associated with a significant export flux of carbon and $\mathrm{CO}_{2}$ draw-down. The smaller flagellated algae dominate in areas of low biomass, and although they may occasionally form blooms, their role in the biogeochemical cycles of the Southern Ocean ecosystem is considered less important due to their low sedimentation rates (Smetacek 1985, Michaels \& Silver 1988). Different types of Southern Ocean phytoplankton blooms in the Ross Sea are showing significant differences in terms of carbon export (Arrigo et al. 1999). However, in this paper we concentrate on the physiological responses of phytoplankton to their light environment as a means of explaining phytoplankton biomass and productivity within different zones of the Southern Ocean.

Phytoplankton photosynthetic rates respond to variations in the light regime by photoacclimational processes (Prezelin \& Sweeney 1979, Falkowski \& Owens 1980, Perry et al. 1981, Platt et al. 1982, Neori et al. 1984); 3 of these processes will be dealt with here: the absorption of light by phytoplankton, the characteristics of photosynthesis as a function of irradiance (P vs $E$ curves) and variations in pigment composition. This information is used both to explain the observed biomass and taxonomic distribution patterns and to calculate areal primary production rates.

In early austral summer 1995/1996 we investigated phytoplankton distribution and photosynthetic characteristics in the Atlantic Sector of the Southern Ocean. Areal daily production rates were determined by using $P$ vs $E$ parameters in consideration of the spectral resolution of the underwater light field and absorbance by phytoplankton. The results were related to zooplankton grazing, nutrient conditions and hydrography to provide insight into the factors which determine differences in phytoplankton composition and primary production in this part of the Southern Ocean.

\section{MATERIALS AND METHODS}

Work at sea. Data were collected from 24 openwater stations in the region $49^{\circ}-67^{\circ} \mathrm{S}, 6^{\circ} \mathrm{W}-12^{\circ} \mathrm{E}$ in the Atlantic Sector of the Southern Ocean during the JGOFS cruise ANT XIIL/2 (December 1995 to January 1996) on RV 'Polarstern' (Fig. 1). Seventeen stations were sampled and profiled down to $120 \mathrm{~m}$ depth ( $\mathrm{S} 6$, S8-S10, S13-S16, S18-S21, S25, S29-S32). At 7 stations, only surface water was sampled (F4, F6-F11). Icebergs were seen in the vicinity of Stns F4, F6, S8 and S31, and S30 was close to the ice edge.

Physical characteristics. The physical characteristics of the water column were determined with a CTD (NBIS Mark III), connected to a General Oceanics BioRosette water sampler with $24 \times 121$ bottles. The depth of the upper mixed layer (UML) was defined as a $>0.05$ change in sigma-t over a $10 \mathrm{~m}$ depth interval, determined by evaluation of CTD profiles (Strass et al. 1997).

Radiation measurements. Vertical profiles of the downwelling spectral distribution of the underwater light field were measured as described in Bracher \& Tilzer (1998) using a MER-2040 underwater spectrora- 


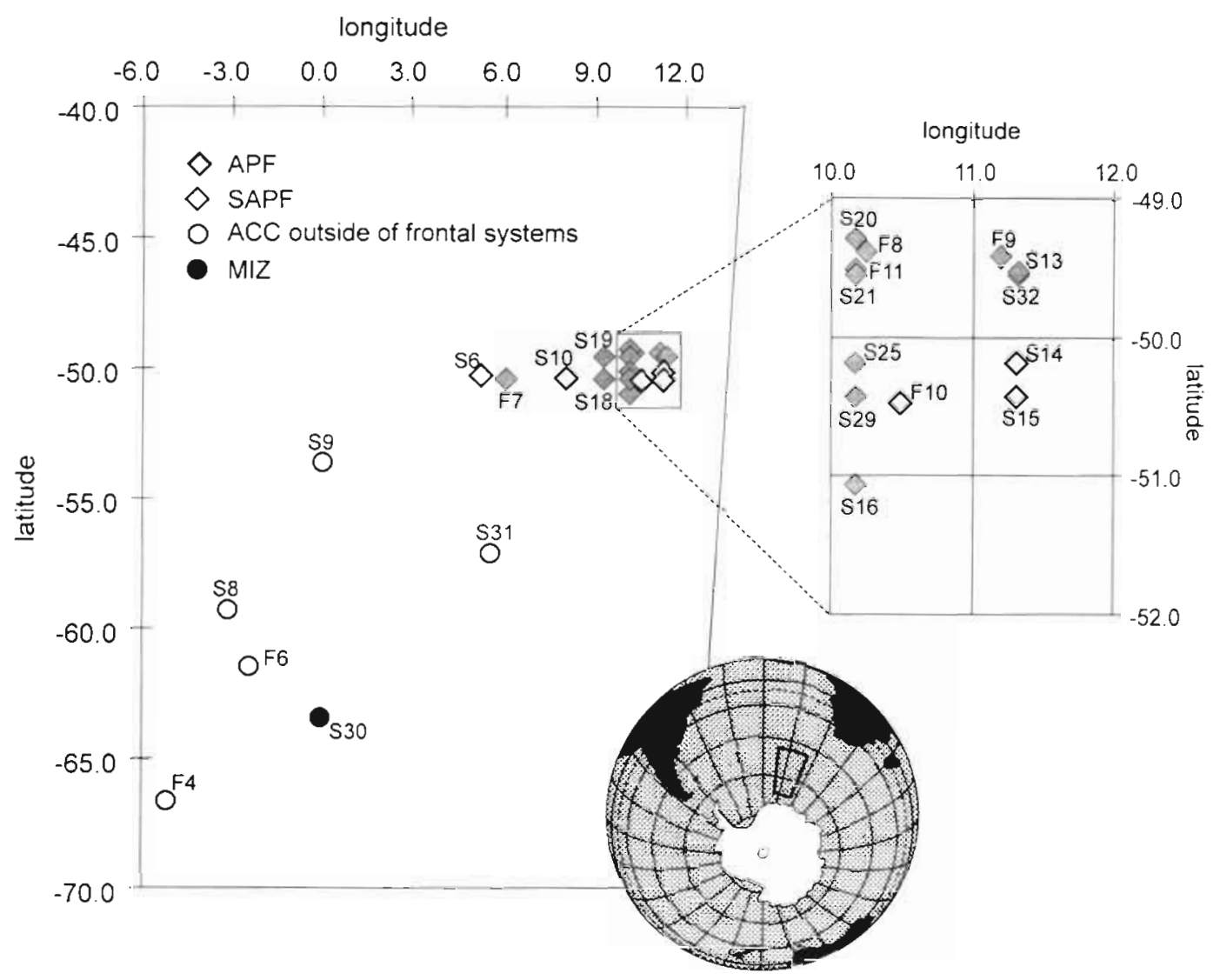

Fig. 1. Cruise area studied during the JGOFS cruise ANT XIII/2 in the early austral summer 1995/1996. Stations were located in the Antarctic Polar Front (APF), south of the APF (SAPF), Antarctic Circumpolar Current outside of frontal systems (ACC) and the marginal ice zone (MIZ) within the Atlantic Sector of the Southern Ocean

diometer (Biospherical Instruments, San Diego, USA). Underwater light was measured at wavelengths of 412 , $443,465,490,510,520,550,560,615,633,665$ and 683 $\mathrm{nm}$ (10 $\mathrm{nm}$ bandwidth) at various times during the day. In addition, photosynthetically available radiation (PAR, 400 to $700 \mathrm{~nm}$ ) in air was continuously measured at 10 min intervals, using a Li-Cor cosine sensor (Li193SA) mounted on the sun-exposed forward superstructure of the ship.

Water sample analysis and experiments. Water was sampled at CTD stations by means of the Bio-Rosette whereas surface stations were sampled with a bucket. At the CTD stations, pigment composition, particulate light absorption and measurements of photosynthetic activity were determined at 6 depths in the euphotic zone. P vs E curves were constructed with water samples from the surface and the $1 \%$ light depth (ranking from 24 to $69 \mathrm{~m}$ ) only.

Chlorophyll concentration: Chlorophyll concentrations were determined using the method of Evans et al. (1987). Total chl a was obtained by filtering water samples onto $25 \mathrm{~mm}$ Whatman GF/F filters, and size frac- tions were obtained by filtering separate $1000 \mathrm{ml}$ aliquots through a $20 \mu \mathrm{m}$ Nitex screen and a $2.0 \mu \mathrm{m}$ Nuclepore filter. These filtrates were retained on GF/F filters to yield chl a concentrations within the $<20$ and $<2.0 \mu \mathrm{m}$ fractions. Pigments retained on the filters were extracted in $90 \%$ acetone/water for 2 to $3 \mathrm{~h}$ in a dark refrigerator and homogenised in a cell mill for 5 min. Thereafter, the sample was centrifuged, the supernatant transferred into a quartz tube, and fluorescence read on a Turner Designs scaling fluorometer before and after acidification with 2 drops of $5 \% 1 \mathrm{~N}$ $\mathrm{HCl}$. For Stns S6, S14, S19, S20 and S25 only total chl a data are available (Hense et al. 1998).

Particulate light absorption: Microalgae and other particulates were collected onto Whatman GF/F filters. The absorption coefficient $\left(a[\lambda], \mathrm{m}^{-1}\right)$, corrections for detritus absorption $\left(a_{d}[\lambda], \mathrm{m}^{-1}\right)$, and the chl $a$-specific absorption coefficient $\left(a_{\phi} \cdot[\lambda], \mathrm{m}^{2} \mathrm{mg} \mathrm{chl} a^{-1}\right)$ were determined by the method of Yentsch (1962), as modified by Bricaud \& Stramski (1990), using the B-correction of Mitchell \& Kiefer (1988). The mean chl a-specific absorption coefficient of $\operatorname{PAR}\left(\bar{a}_{\phi}{ }^{\circ}, \mathrm{m}^{2} \mathrm{mg} \mathrm{chl} a^{-1}\right)$, 
Table 1. List of symbols and abbreviations used in the text

\begin{tabular}{|c|c|c|}
\hline Symbol & Definition & Units \\
\hline$\alpha^{\cdot}$ & Maximum light utilisation coefficient & $\begin{array}{l}\text { mg C mg chl } a^{-1} h^{-1} \\
\left(\mu \text { mol photons } \mathrm{m}^{-2} \mathrm{~s}^{-1}\right)^{-1}\end{array}$ \\
\hline$a[\lambda]$ & Absorption coefficient & $\mathrm{m}^{-1}$ \\
\hline $\mathrm{ACC}$ & Antarctic Circumpolar Current & \\
\hline$a_{\mathrm{d}}[\lambda]$ & Detritus absorption coefficient & $m^{-1}$ \\
\hline ADP & Areal daily primary production & $m g C^{-2} d^{-1}$ \\
\hline$a_{0} \cdot[\lambda]$ & Chl a-specific absorption coefficient & $\mathrm{m}^{2} \mathrm{mg} \mathrm{chl} a^{-1}$ \\
\hline$a_{0} \cdot$ & Mean chl a-specific absorption coefficient of PAR & $\mathrm{m}^{2} \mathrm{mg} \operatorname{chl} a^{-1}$ \\
\hline APF & Antarctic Polar Front & \\
\hline$B_{c}$ & Chl a biomass & 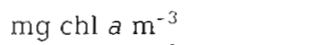 \\
\hline $\bar{B}_{\mathrm{c}}$ & Average chl a biomass within the euphotic zone & $\mathrm{mg} c h l a \mathrm{~m}^{-3}$ \\
\hline$E$ & Downwelling irradiance & $\mu \mathrm{mol}$ photons $\mathrm{m}^{-2} \mathrm{~s}^{-1}$ \\
\hline$E_{\mathrm{c}}$ & Downwelling irradiance in the air & $\mu \mathrm{mol}$ photons $\mathrm{m}^{-2} \mathrm{~s}^{-1}$ \\
\hline$E_{\mathrm{d}}(0)$ & Downwelling irradiance in subsurface water & umol photons $\mathrm{m}^{-2} \mathrm{~s}^{-1}$ \\
\hline $\bar{E}_{\mathrm{d}}(0)$ & Daily mean for subsurface downwelling irradiance & $\mu \mathrm{mol}$ photons $\mathrm{m}^{-2} \mathrm{~s}^{-1}$ \\
\hline$E_{k}$ & Light saturation parameter & $\mu \mathrm{mol}$ photons $\mathrm{m}^{-2} \mathrm{~s}^{-1}$ \\
\hline$\Phi_{\mathrm{m}}$ & Maximum quantum yield & mol C (mol photons) ${ }^{-1}$ \\
\hline$\hat{k}_{\mathrm{d}}[\mathrm{PAR}]$ & Mean vertical light attenuation coefficient of PAR & $\mathrm{m}^{-1}$ \\
\hline$k_{\mathrm{d}}[\mathrm{PAR}](z)$ & Light attenuation coefficient of PAR at depth $z$ & $\mathrm{~m}^{-1}$ \\
\hline MIZ & Marginal ice zone & \\
\hline$N$ & Daylength & $\mathrm{h}$ \\
\hline$P^{\cdot}$ & Biomass-specific photosynthetic production rate & $\operatorname{mgC} \cdot \operatorname{mgchl} a^{-1} h^{-1}$ \\
\hline$P \cdot{ }_{m}$ & Maximum $P^{*}$ & $\mathrm{mgC} \cdot \mathrm{mg} \operatorname{chl~} a^{-1} \mathrm{~h}^{-1}$ \\
\hline PAR & Photosynthetic active radiation; $400-700 \mathrm{~nm}$ & $\mu \mathrm{mol}$ photons $\mathrm{m}^{-2} \mathrm{~s}^{-1}$ \\
\hline SAPF & Stations within the ACC located just south of the APF & \\
\hline UML & Upper mixed layer & \\
\hline$Z_{\mathrm{rn}}$ & $\begin{array}{l}\text { Maximum depth of integration, defined by the depth at } \\
\text { which irradiance was } \geq 1 \mu \text { mol photons } \mathrm{m}^{-2} \mathrm{~s}^{1} \text { at daily } \\
\text { maximum surface irradiance }\end{array}$ & $\mathrm{m}$ \\
\hline$Z_{r \mathrm{r}}$ & Critical depth & $\mathrm{m}$ \\
\hline
\end{tabular}

weighted according to the spectral irradiance of the light source, was calculated using the equation of Atlas \& Bannister (1980). For further details see Bracher \& Tilzer (1998).

$\boldsymbol{P}$ vs $\boldsymbol{E}$ measurements: The relationship between algal photosynthesis and irradiance was examined at 22 stations. Samples were incubated at in situ temperatures in a small volume $(20 \mathrm{ml})$ 'photosynthetron' (from S. Pilo, Bar-Ilan University, Israel). Each $20 \mathrm{ml}$ sample was spiked with ${ }^{14} \mathrm{C}$ (concentration of 2.8 to 3.5 $\times 10^{10} \mathrm{~Bq} \mathrm{ml} l^{-1}$ ). Eighteen subsamples of each sample were incubated under a $200 \mathrm{~W}$ tungsten halogen lamp. Photon flux $(E)$ ranged from 1 to 600 (for Stns $\$ 30$ to S32 up to 1000) $\mu \mathrm{mol}$ photons $\mathrm{m}^{-2} \mathrm{~s}^{-1}$ (measured with a Biospherical Instrument $4 \pi$ probe, QSP200). After incubation, samples were filtered onto Sartorius cellulose nitrate filters $(0.45 \mu \mathrm{m}$ pore size) and exposed to fuming $\mathrm{HCl}$ in a dessicator for $15 \mathrm{~min}$ to release unassimilated ${ }^{14} \mathrm{CO}_{2}$. After adding scintillation cocktail (Quickszint 361), samples were counted in a Packard 1900CA Tri-Carb Liquid Scintillation Counter. The uptake of ${ }^{14} \mathrm{C}$ labelled bicarbonate into acid-stable organic material was converted to chlorophyll-specific rates using measured values of chl a concentration and alkalinity (from Stoll et al. 1997) and following the protocol of Strickland \& Parsons (1972). P versus E curve data were fitted to the equation of Webb et al. (1974), which excludes photoinhibition, because no photoinhibition was detected in our samples

$$
P^{*}=P_{m}^{*}\left\{1-\exp \left[-\left(E \alpha^{*}\right) / P^{*}{ }_{m}\right)\right\}
$$

All symbols are explained in Table 1. The spectral dependent parameter $\alpha^{*}$ from samples taken at depth $z$ was corrected to approximate maximum light utilisation coefficient in situ according to the relationship in Lewis et al. (1985):

$$
\begin{aligned}
& \alpha^{*}{ }_{\text {spectraliy corrected }}(z)=\left[\left(\alpha^{*}{ }_{\text {incubator }}(z) \cdot \bar{a}_{\phi}{ }^{*} \text { in snu }(z)\right] /\right. \\
& \overline{\mathrm{a}}_{\Phi}{ }^{*} \text { incubator }(z)
\end{aligned}
$$

The light saturation parameter $E_{k}(z)$ was calculated from the $P^{*}{ }_{m}(z): \alpha{ }^{*}$ spectrally corrected $(z)$ ratio.

Maximum quantum yield $\Phi_{\mathrm{m}}\left[\mathrm{mol} \mathrm{C}\right.$ (mol photons) $\left.{ }^{-1}\right]$ was calculated according to Bannister (1974):

$$
\Phi_{\mathrm{m}}(z)=\alpha^{\cdot} \text { spectrally corrected }(z) / \bar{\alpha}_{\emptyset}{ }^{\cdot} \text { in situ }(z)
$$

Photosynthetic pigment composition: Pigment composition was determined by high performance liquid chromatography (HPLC). Samples of 1.0 to 2.0 l were 
filtered onto $25 \mathrm{~mm}$ Whatman GF/F filters to retain pigments. These were placed in Eppendorf tubes and immediately frozen in liquid nitrogen. The filters were then stored at $-80^{\circ} \mathrm{C}$ for about 8 mo prior to pigment extraction in $90 \%$ acetone and subsequent HPLC analysis of the pigment extracts at the AWI, Bremerhaven, Germany. HPLC protocols followed those of Karsten \& Garcia-Pichel (1996) with some modifications. After evaporation of the pigment extracts under a stream of nitrogen, they were redissolved in $100 \mu \mathrm{l}$ $100 \%$ acetone. Pigments were separated using a Waters Associates HPLC system which includes a 600 MS gradient module with system controller and a Model 996 photodiode array detector. Samples $(80 \mu \mathrm{l})$ were injected into the HPLC column by an autosampler (717 plus). The column was a stainless-steel Merck LiChrospher RP 18 cartridge (5 um packing; $12.5 \mathrm{~mm} \times$ $4 \mathrm{~mm}$ inner diameter [i.d.]) behind a Merck RP 18 guard column ( $4 \mathrm{~mm} \times 4 \mathrm{~mm}$ i.d.) filled with the same material. Pigments were monitored at $436 \mathrm{~nm}$ and separated by a binary gradient system of helium-degased solvents. The mobile phase of solvent A (distilled water) and solvent $B$ (acetonitiril-methanol-tetrahydrofuran, 75:15:10, vol/vol) was regulated at a flow rate of $1.5 \mathrm{ml} \mathrm{min}^{-1}$ using the following program: 0 to $15 \mathrm{~min}$ for a linear increase from $15 \%$ solvent $\mathrm{A}$ to $100 \%$ solvent B and 15 to $24 \mathrm{~min}$ for $100 \%$ solvent $\mathrm{B}$.

The individual pigments were identified by their absorption at $436 \mathrm{~nm}$ in a mixture of solvent $A$ and solvent $B$ at the appropriate retention time. Their identification was evaluated against co-chromatography with commercially available standards (The International Agency for ${ }^{14} \mathrm{C}$ Determination, VKI, Denmark). Pigments were quantified by peak area with reference to response signals obtained from the standards using the Waters 996 photodiode array detector and integrator. Additional confirmation for each pigment was done by using on-line diode array absorbance spectra between 300 and $700 \mathrm{~nm}$.
Estimation of the contribution of chl a by different algal groups: Ratios of chl a to accessory pigments characteristic of each algal group were obtained from previous studies. We used the equations used by Letelier et al. (1993) and modified by Peeken (1997) who also studied phytoplankton 'fingerprints' in the same area of the Southern Ocean (Table 2). The ratios of chl a to accessory pigments for each algal group obtained within a water sample were compared with phytoplankton counts (Hense et al. 1998) obtained at Stns S9, S13-S16, S18-S21, S25, S29, S32 and F7-F11 Phytoplankton samples from Stns S6, S8, S10, S30, S31, F4, F6 were counted by the authors and $M$. Schültke (unpubl. data).

Areal daily primary production including light intercalibrations: The following parameters were used and derived to obtain areal daily primary production:

(1) The immediate subsurface downwelling irradiance $E_{\mathrm{d}}(0)$ was determined from $E_{\mathrm{d}}(0)=E_{\mathrm{a}} I$, where $E_{\mathrm{a}}=$ downwelling irradiance in air. The conversion factor $r$ was determined to equal $0.75621 \mathrm{n}=20, \mathrm{SD}=$ 0.05149 ).

(2) Vertical light attenuation coefficients of PAR were estimated by first integrating irradiance fluxes in the 12 wavelengths measured and assuming that they were valid for the entire waveband in which at the mid-point irradiance was measured. The vertical attenuation coefficients of PAR at a discrete depth, $k_{\mathrm{d}}[\mathrm{PAR}](z)$, were determined from the expression in Smith \& Baker (1978) for deriving $k_{d}$ at a specific wavelength:

$$
-k_{\mathrm{d}}[\mathrm{PAR}](z)=\left\{\ln E_{\mathrm{d}}[\mathrm{PAR}](z)-\ln E_{\mathrm{d}}[\mathrm{PAR}](0)\right\} / z
$$

(3) The value of the chl a biomass, $B_{c}$, was determined from the chl a concentrations at the discrete depths sampled and interpolated for depths in between.

(4) The primary production rate $P^{*}$ was determined at time $t$ and at a specific depth $z_{1}$ from

Table 2. Equations used to determine the chl a contribution of the different algal groups to the measured total chl $a$ (from Letelier et al. 1993, modified by Peeken 1997). HEXA: 19' -hexanoyloxyfucoxanthin; BUT. 19'-butanoyloxyfucoxanthin; FUCO: fucoxanthin; chl a: chlorophyll $a_{i}$ chl $b$ : chlorophyll $b ;$ prym: Prymnesiophyceae; baci: Bacillariophyceae; chrys: Chrysophyceae; dino: Dinophyceae; chloro: Chlorophyceae; crypt: Cryptophyceae

\begin{tabular}{|c|c|}
\hline Algal group & Pigment ratio \\
\hline Prymnesiophyceae & $\begin{array}{l}{[\mathrm{chl} a]_{\mathrm{prym}}=0.9[\mathrm{HEXA}]_{\mathrm{rr} ; \mathrm{m}}} \\
{[\mathrm{HEXA}]_{\mathrm{prym}}=1.0026([\mathrm{HEX} \lambda]-0.14[\mathrm{BUT}])}\end{array}$ \\
\hline Bacillariophyceae & {$[\mathrm{chl} a]_{\text {boci }}=0.8[\mathrm{FUCO}]-\left(0.02[\mathrm{HEXA}]_{\mathrm{prym}}+0.14\left[\mathrm{BUT} \mathrm{T}_{\text {chrys }}\right]\right)$} \\
\hline Dinophyceae & {$[\mathrm{chl} a]_{\text {dino }}=1.4 \mid$ peridinin $\mid$} \\
\hline Chlorophyceae & {$[\mathrm{chl} a]_{\text {chloro }}=2.4[\mathrm{chl} b]-2.1[$ prasinoxanthin $]$} \\
\hline Chrysophyceae & $\begin{array}{l}{[\text { chl a }]_{\text {chrys }}=0.9 B U T_{\text {chrys }}} \\
\text { BUT }_{\text {chrys }}=1.0026([\mathrm{BUT}]-([\mathrm{HEXA}] / 54.27)\end{array}$ \\
\hline Cryptophyceae & {$[\mathrm{chl} a]_{\text {crypt }}=4.2[$ alloxanthin $]$} \\
\hline
\end{tabular}




$$
E_{\mathrm{d}}(t, z)=E_{\mathrm{d}}(t, 0) \cdot \exp \left(-k_{\mathrm{d}}[\mathrm{PAR}](z) \cdot z\right)
$$

using the following equation:

$$
P^{\cdot}(t, z)=B_{\mathrm{c}}(z) P_{\mathrm{m}}(z) \cdot\left\{1-\exp \left[-E_{\mathrm{d}}(t, z) \cdot \alpha^{\cdot}(z) / P^{\cdot}(z)\right]\right\}
$$

(5) To derive the areal daily primary production, $\operatorname{ADP}\left(\mathrm{mg} \mathrm{C} \mathrm{m}^{-2} \mathrm{~d}^{-1}\right.$ ), we integrated over the depth and over the time of $1 \mathrm{~d}$. The maximum depth of integration $Z_{\mathrm{m}}$ is defined at the depth at which the irradiance was $\geq 1 \mu \mathrm{mol}$ photons $\mathrm{m}^{-2} \mathrm{~s}^{-1}$ at the maximum surface irradiance during the day. Only values of $E_{\mathrm{d}}(\mathrm{t}, 0) \geq 1 \mu \mathrm{mol}$ photons $\mathrm{m}^{-2} \mathrm{~s}^{-1}$ were used:

$$
\mathrm{ADP}=\Sigma \begin{array}{ll}
t=24 \mathrm{~h} & z=Z_{\mathrm{m}} \\
t=0 & \Sigma \mathrm{P} \cdot(z, t) \\
& z=0
\end{array}
$$

To compare our results with ADP rates obtained by other calculation methods, additional parameters were determined. The daylength, $N$, was determined from the time at which immediate subsurface downwelling irradiance, $E_{\mathrm{d}}(0)$, was $>1 \mu \mathrm{mol}$ photons $\mathrm{m}^{-2} \mathrm{~s}^{-1}$. These values were used to calculate the daily mean value of subsurface downwelling irradiance $\bar{E}(0)$.

We used a reformulated version of Sverdrup's critical depth equation (Nelson \& Smith 1991) to derive an estimate of the depth at which the vertically integrated rates of photosynthesis and phytoplankton respiration were equal:

$$
Z_{\mathrm{cr}}=E_{\mathrm{d}}[\mathrm{PAR}](0)+/ 3.78 \hat{k}_{\mathrm{d}}[\mathrm{PAR}]
$$

where $E_{\mathrm{d}}[\mathrm{PAR}](0)+$ is the flux of PAR at the sea surface integrated over $24 \mathrm{~h}$ and the mean vertical attenuation coefficient of PAR, $\hat{k}_{d}[\mathrm{PAR}]$, was determined from linear regression analysis of the natural logarithms of PAR at 25 incremental depth points for each determination. The value thus obtained was assumed to be representative for the centre of the depth range considered. Correlations in these regression analyses were extremely high $(>0.99)$.

\section{RESULTS}

\section{Sampling sites and phytoplankton biomass}

The cruise transect from $49^{\circ} \mathrm{S}$ to $67^{\circ} \mathrm{S}$ comprised 3 different zones, according to the description by Tréguer \& Jacques (1992); viz. the Antarctic Polar Front (APF), the Antarctic Circumpolar Current outside of frontal systems (ACC) and the marginal ice zone (MIZ). One station (S30) occurred in the MIZ and 13 stations (F7-F9, F11, S13, S16, S18-S21, S25, S29 and S32) occurred within the APF. Five stations (F10,

\begin{tabular}{|c|c|c|c|c|c|}
\hline & Total & APF & SAPF & $\mathrm{ACC}$ & MIZ \\
\hline PAR daily maxima in air & $600-2900$ & $1200-2000$ & $1300-2000$ & $600-2900$ & $1300-2900$ \\
\hline PAR daily maxima at surface & $400-2200$ & $900-1500$ & $1000-1500$ & $400-2200$ & $1000-2200$ \\
\hline$Z_{\mathrm{eu}}(\mathrm{m})$ & $28-90$ & $28-50$ & $67-78$ & $73-90$ & 40 \\
\hline$Z_{(M 1 L}(\mathrm{m})$ & $12-77$ & $15-35$ & $35-77$ & $50-60$ & 12 \\
\hline$Z_{\mathrm{cr}}(\mathrm{m})$ & $36-200$ & $36-70$ & $40-160$ & $80-200$ & 75 \\
\hline $\mathrm{Chl} a$ in euphotic zone & $0.15-2.43$ & $0.90-1.79$ & $0.15-0.77$ & $0.20-0.46$ & $0.88-2.43$ \\
\hline Daylength & $14-24$ & $16-17.5$ & $14-17$ & $17-20.5$ & $20-24$ \\
\hline$P_{m}^{*}(100 \%)$ & $0.66-3.1$ & $0.83-3.1$ & $0.71-1.41$ & $0.66-1.13$ & 1.28 \\
\hline$P_{m}(1 \%)$ & $0.27-3.2$ & $1.30-3.2$ & $1.05-3.2$ & 0.27 & 1.06 \\
\hline$\alpha^{*}(100 \%)$ & $0.006-0.027$ & $0.009-0.022$ & $0.006-0.009$ & $0.014-0.027$ & 0.0080 \\
\hline$\alpha^{\bullet}(1 \%)$ & $0.014-0.06$ & $0.014-0.032$ & $0.015-0.06$ & 0.034 & 0.014 \\
\hline$E_{k}(100 \%)$ & $34-246$ & $74-246$ & $75-180$ & $34-83$ & 160 \\
\hline$E_{k}(1 \%)$ & $8-139$ & $56-139$ & $50-70$ & 8 & 78 \\
\hline$\Phi_{\mathrm{m}}(100 \%)$ & $0.006-0.035$ & $0.024-0.035$ & $0.006-0.014$ & $0.018-0.024$ & 0.014 \\
\hline$\Phi_{m}(1 \%)$ & $0.020-0.093$ & $0.040-0.093$ & $0.020-0.058$ & 0.025 & 0.047 \\
\hline $\bar{a}_{\varphi} \cdot(100 \%)$ & $0.006-0.027$ & $0.006-0.017$ & $0.016-0.027$ & $0.011-0.020$ & 0.014 \\
\hline $\bar{a}_{0} \cdot(1 \%)$ & $0.006-0.03$ & $0.006-0.018$ & $0.016-0.030$ & 0.029 & 0.007 \\
\hline \multirow[t]{4}{*}{ Stations } & & $\mathrm{S} 13, \mathrm{~S} 16, \mathrm{~S} 18$ & S6, S10,S14 & $\mathrm{S} 8, \mathrm{~S} 9, \mathrm{~S} 31$ & $\mathrm{~S} 30$ \\
\hline & & $\mathrm{S} 19, \mathrm{~S} 20, \mathrm{~S} 21$ & S15,F10 & F4, F6 & \\
\hline & & $\mathrm{S} 29, \mathrm{~S} 32, \mathrm{~F} 7$ & & & \\
\hline & & $\mathrm{F} 8, \mathrm{Fg}, \mathrm{F} 11$ & & & \\
\hline
\end{tabular}

Table 3. Maxima and minima of PAR in the air and at the sea surface, euphotic depths $\left(Z_{*}\right)$, depth of upper mixed layer $\left(Z_{\text {UmuL }}\right)$, critical depth $\left(Z_{\mathrm{cr}}\right), \mathrm{chl}$ a concentrations (chl a), $P^{*} \mathrm{~m}, \alpha^{*}, E_{k}, \Phi_{\mathrm{m}}$ and $\bar{a}_{6}{ }^{*}$ values from surface $(100 \%)$ and $1 \%$ light depth (1\%) in the Atlantic Sector of the Southern Ocean in early summer 1995/1996. Total: all stations; APF: stations within the Antarctic Polar Front; SAPF: stations south of the Antarctic Polar Front; ACC: stations within the Antarctic Circumpolar Current; MIZ: stations within the marginal ice zone. Units are shown in Table 1 
S6, S10, S14, S15) within the ACC were located just south of the APF (termed SAPF) between $50.2^{\circ} \mathrm{S}$ and $51.1^{\circ} \mathrm{S}$. The remaining 5 stations (F4, F6, S8, S9, S31) were located further south (>53.5 $\mathrm{S}$ ) within the ACC (Fig. 1).

UML depths for the stations within the APF varied between 15 and $35 \mathrm{~m}$, while UML depths of the SAPF and southern ACC stations always exceeded 35 and $50 \mathrm{~m}$, respectively (Fig $2 a-c$, Table 3). Although Stn S30 was north of the ice edge (van Franeker \& van den Brink 1997), it is still considered to belong to the MIZ, since the depth profile of salinity indicated sea ice meltwater inflow into the surface layer, resulting in a shallow UML depth of $<15 \mathrm{~m}$ (Fig. 2d). In addition, the many icebergs seen in the vicinity of this station (van Franeker \& van den Brink 1997) probably contributed to the fresher surface water.

Surface seawater temperatures (SST) across the APF ranged from 4 to $5^{\circ} \mathrm{C}$ and in the SAPF from $<2$ to $4^{\circ} \mathrm{C}$. Further south in the ACC, the SST ranged from -1.5 to $2^{\circ} \mathrm{C}$ and for Stn S30, SST was approximately $0.5^{\circ} \mathrm{C}$

For all station profiles, chl a concentrations ranged from 0.15 to $2.43 \mathrm{mg} \mathrm{m}^{-3}$ over the upper $40 \mathrm{~m}$. Maximum values were found in the MIZ $\left(0.88\right.$ to $\left.2.43 \mathrm{mg} \mathrm{m}^{-3}\right)$. In the APF, values reached $1.8 \mathrm{mg} \mathrm{chl} a \mathrm{~m}^{-3}$, while in the SAPF and the ACC, maxima were $<0.8$ and $<0.5 \mathrm{mg}$ chl a m $\mathrm{m}^{-3}$ respectively (Table 3 ).

\section{Phytoplankton community composition}

The composition of the phytoplankton community at all stations was described on the basis of pigment data determined by HPLC analyses (Fig. 3). Within the APF, the contribution of diatoms to the total phytoplankton biomass was 60 to $80 \%$; dinoflagellates were absent. In the SAPF the diatom fraction of total biomass was only 25 to $45 \%$, whereas dinoflagellate biomass made up 20 to $50 \%$. Microscopy observations on APF samples by Hense et al. (1998) showed the low diversity but high abundance of the highly silicified diatoms Thalassiothrix spp., Pseudonitzschia cf. lineola chains and Chaetoceros spp. which dominated the biomass, whereas the diversity of species in the SAPF was much higher. Some of the diatom species had spines which exceeded $500 \mu \mathrm{m}$. Within the ACC, diatoms, dinoflagellates, prymnesiophytes and chrysophytes all contributed to the biomass. South of $57^{\circ} \mathrm{S}$, at Stns F4, F6 and $\mathrm{S} 8$, diatoms contributed roughly $50 \%$ of the biomass. Within the MIZ (at S30), prymnesiophytes, i.e.
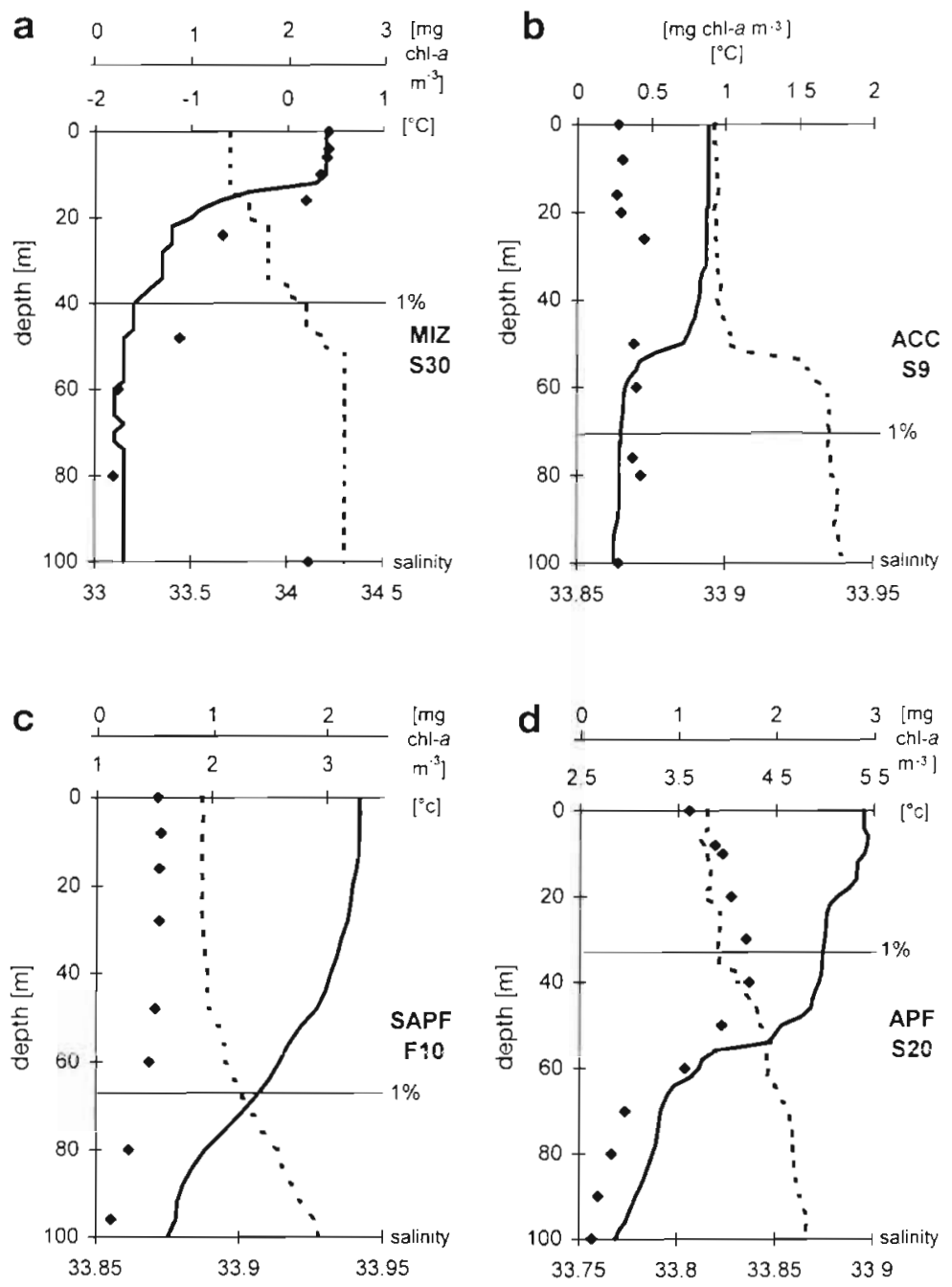

Fig. 2. Vertical profiles of temperature $\left({ }^{\circ} \mathrm{C}\right)(-)$, salinity $(--)$ and chl a concentration $\left(\mathrm{mg} \mathrm{m}^{-3}\right)(\bullet)$, and $1 \%$ light depth $(-)$ at several stations during ANT XIII/2. (a) Stn S30, MIZ; (b) Stn S9, as an example of the ACC $i$ (c) Stn F10, as an example of the SAPF; (d) Stn S20, as an example of the APF. CTD measurement data were obtained from Strass et al. (1997) during ANT XIII/2

Phaeocystis sp. (M. Schultke pers. comm.), made up 50 to $60 \%$ of the phytoplankton biomass and diatoms 30 to $40 \%$.

\section{Light conditions}

Daily maximum surface PAR ranged from 400 to $2200 \mu \mathrm{mol}$ photons $\mathrm{m}^{-2} \mathrm{~s}^{-1}$, with both the highest and lowest values occurring in the ACC region. Within the $\mathrm{MIZ}$, the range was 1000 to $2200 \mu \mathrm{mol}$ photons $\mathrm{m}^{-2} \mathrm{~s}^{-1}$ and at the APF 900 to $1500 \mu \mathrm{mol}$ photons $\mathrm{m}^{-2} \mathrm{~s}^{-1}$ (Table 3). The euphotic depth, $Z_{\text {eu }}$ (to $1 \%$ light) ranged 


\begin{tabular}{|ll|}
\hline$\square$ Dinophyceae & QChrysophyceae \\
- Diatoms & BPrymnesiophyceae \\
\hline
\end{tabular}

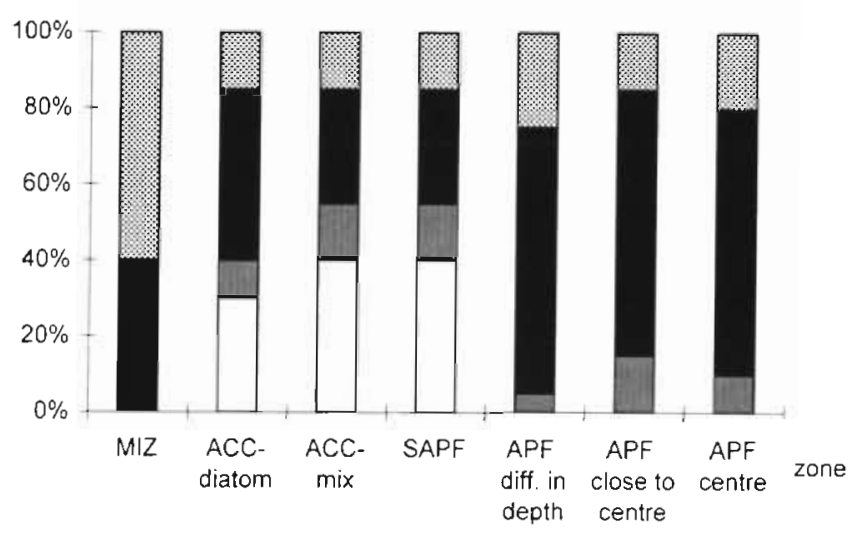

Fig. 3. Phytoplankton composition within the different areas of our study. Ratios (\%) of each algal group were obtained by converting characteristic accessory pigment concentrations to chl a according to Table 2 and relating it to the total extracted chi a. All pigments for this calculation were determined by HPLC analyses. APF diff. (different) in depth: stations in this area where the $P^{\cdot}$ values from $1 \%$ light depth were significantly higher than at the surface. ACC-diatom: stations in the area of the ACC close to the ice edge with a high proportion of diatoms in the phytoplankton community. ACC-mix: stations in the area of the ACC with equal contributions of phytoplankton groups in the community

from 28-50 $\mathrm{m}$ within the APF to 73-90 $\mathrm{m}$ within the ACC, while $Z_{\text {eu }}$ for the MIZ was intermediate at $40 \mathrm{~m}$, light attenuation here being due to a Phaeocystis sp. bloom (Table 3). Elsewhere, the shallowest $Z_{\text {eu }}$ depths coincided with maximum chlorophyll concentrations associated with the diatom bloom. Daylength in the 3 regions ranged from 16 up to $24 \mathrm{~h}$ (Table 3), increasing at higher latitudes.

$$
\bar{a}_{0} \cdot \text { values }
$$

$\bar{a}_{0} \cdot$ ranged from 0.006 to $0.030 \mathrm{~m}^{2} \mathrm{mg} \mathrm{chl} a^{-1}$, averaging 0.016 (Table 3). The minimum was found in the APF (S20 at $80 \mathrm{~m}$ ) and the maximum in the SAPF (S15 at $60 \mathrm{~m})$.

\section{P vs E parameters}

The $P$ vs $E$ parameter, $P \cdot m$ ranged from 0.27 to $3.20 \mathrm{mg} \mathrm{C} \mathrm{mg} \mathrm{chl} a^{-1} \mathrm{~h}^{-1}$. The minimum $P_{\mathrm{m}}$ value was measured within the $A C C$ and the maximum within the SAPF and the APF (Fig. 4a-c). Significant differences between surface water and $1 \%$ light depth $P^{*}$ values were evident at most stations. At all stations within the ACC and MIZ, surface water $P_{m}^{\cdot}>1 \%$ light depth $P_{m}^{*}$ (Fig. 4a). Conversely, at all stations within the SAPF and at S13, S16, S18 and S32 of the APF, surface water $P_{\mathrm{m}}^{*}<1 \%$ light depth $P_{\mathrm{m}}^{*}$ (Fig. 4b). At all other stations within the APF, surface and $1 \%$ light depth $P^{*}$ values were insignificantly different (Fig. 4c), with the exception of S21, where the surface water $P_{m}^{*}>1 \%$ light depth $P_{\mathrm{m}}^{*}$.

For all regions, $E_{k}$ at the $1 \%$ light depth ranged from 8 to $139 \mu \mathrm{mol}$ photons $\mathrm{m}^{-2} \mathrm{~s}^{-1}$; it was higher at the surface: 34 to $246 \mu \mathrm{mol}$ photons $\mathrm{m}^{-2} \mathrm{~s}^{-1}$. Consistently low $E_{k}$ values ( 8 to $83 \mu \mathrm{mol}$ photons $\mathrm{m}^{-2} \mathrm{~s}^{-1}$ ) were only evident within ACC waters. The initial inear slope of the $P$ vs $E$ curve, $\alpha^{*}$, ranged from 0.006 to $0.06 \mathrm{mg} \mathrm{C} \mathrm{mg} \mathrm{chl} a^{-1} \mathrm{~h}^{-1}$ ( $\mu \mathrm{mol}$ photons $\left.\mathrm{m}^{-2} \mathrm{~s}^{-1}\right)^{-1}$ (Table 3). The maximum value and the minimum value of $\alpha^{*}$ were found within the SAPF. Within the MIZ, $P^{*}$ and $\alpha^{*}$ fell between the extremes of the other regions. At all stations, $\alpha^{*}$ at the $1 \%$ light depth was significantly higher than at the surface.
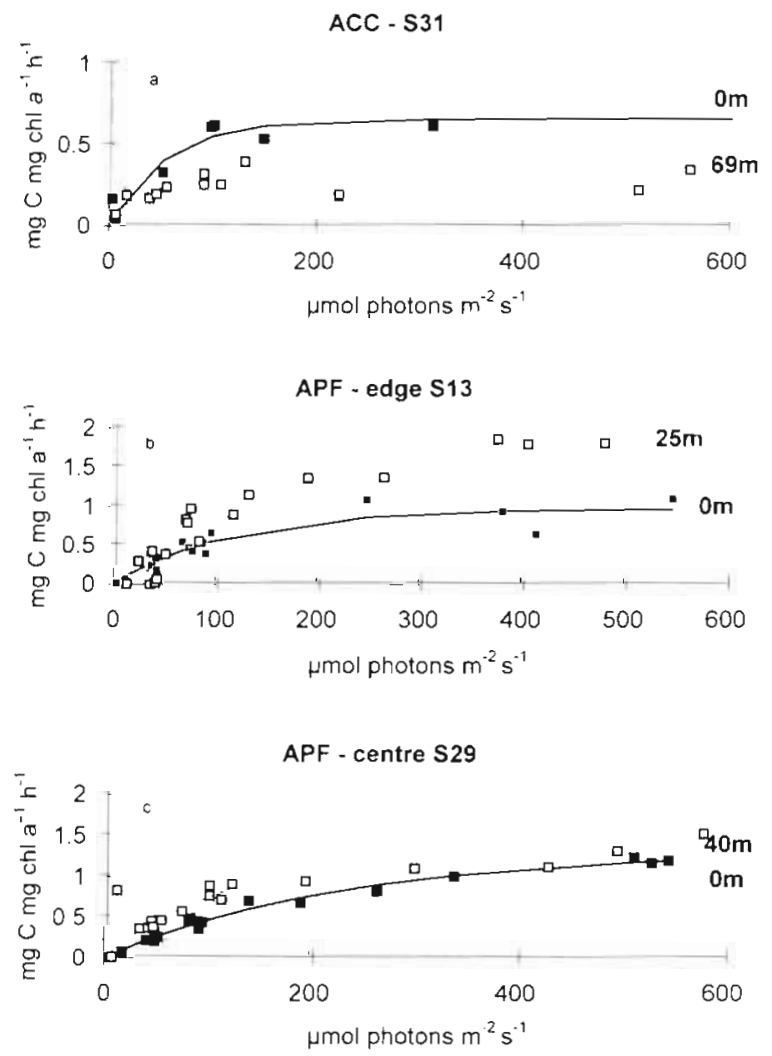

Fig. 4. P vs E curves from (a) S31 in the ACC, where $P^{*}{ }_{m} 1 \%$ light depth $<P^{*}{ }_{m}$ surface; (b) $\$ 13$ from the edge of the APF, where $P^{\cdot}{ }_{\text {in }} 1 \%$ light depth $>P^{\cdot}$ in surface; and (c) S29 from the centre of the APF, where $P^{*}{ }_{m} 1 \%$ light depth $=P^{*}{ }_{m}$ surface. Curve fits according to Webb et al. (1974). Symbols are data points 


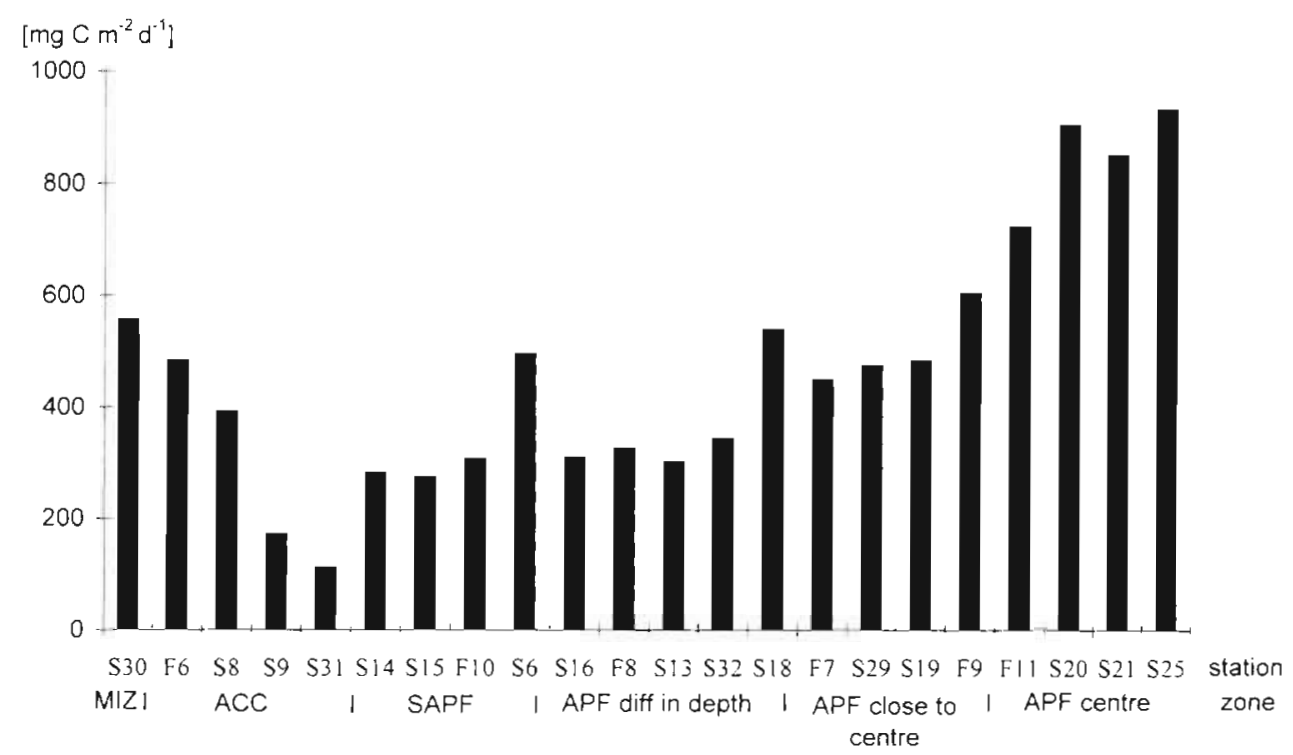

Fig. 5. Areal daily primary production rates at all stations during ANT XII/2. APF diff. (different) in depth: APF stations where $P_{\mathrm{m}} 1 \%$ light depth $>P_{\mathrm{m}}^{\prime}$ surface

Photoinhibition was not observed, but the experimental light conditions did not exceed $1000 \mu \mathrm{mol}$ photons $\mathrm{m}^{-2} \mathrm{~s}^{-1}$.

\section{Maximum quantum yield}

$\Phi_{\mathrm{m}}\left[\mathrm{mol} \mathrm{C}\right.$ (mol photons) $\left.{ }^{-1}\right]$ for all regions ranged from 0.006 to 0.035 at the surface and from 0.02 to 0.093 at the $1 \%$ light depth, therefore showing generally greater efficiency at depth. Surface values from the APF were high $(0.024$ to 0.035$)$ and from the MIZ, low (only 0.014). For the ACC, $\Phi_{m}$ values were intermediate $(0.018$ to 0.024$)$ while for the SAPF, they were very low $(0.006$ to 0.014 ) (Table 3 ).

\section{Areal daily production rates}

Overall, ADP rates ranged from 111 to $932 \mathrm{mg} \mathrm{C}$ $\mathrm{m}^{-2} \mathrm{~d}^{-1}$, with an average value of $470 \mathrm{mg} \mathrm{C} \mathrm{m}^{-2} \mathrm{~d}^{-1}$ (Fig. 5). Daily ADP was highest within the APF at the centre of the bloom (S20, S21, S25 and F11), reaching 734 to $932 \mathrm{mg} \mathrm{C} \mathrm{m}^{-2} \mathrm{~d}^{-1}$. Nearby (at F7, F9, S19 and $\mathrm{S} 29$ ), values were 448 to $604 \mathrm{mg} \mathrm{C} \mathrm{m}^{-2} \mathrm{~d}^{-1}$. In both areas, $P \cdot m$ was similar at the surface and at depth. By contrast, stations at the edge of the APF (at F8, S13, S16 and S32) exhibited much lower ADP values in the range 303 to $334 \mathrm{mg} \mathrm{C} \mathrm{m}^{-2} \mathrm{~d}^{-1}$. Here, the $1 \%$ light depth $P^{\cdot}$ m values were significantly higher than at the surface. However, S18, which also belongs to this zone, showed a high ADP value of $540 \mathrm{mg} \mathrm{C} \mathrm{m} \mathrm{m}^{-2} \mathrm{~d}^{-1}$. Within the SAPF region (S6, $\mathrm{S} 10, \mathrm{~S} 14, \mathrm{~S} 15, \mathrm{~F} 10), P_{\mathrm{m}}$ values also differed in the same way and production was generally low (274 to $327 \mathrm{mg} \mathrm{C} \mathrm{m} \mathrm{m}^{-2} \mathrm{~d}^{-1}$ ), although at $\mathrm{S} 6 \mathrm{ADP}$ reached $496 \mathrm{mg} \mathrm{C} \mathrm{m} \mathrm{m}^{-2} \mathrm{~d}^{-1}$

Within the $\mathrm{ACC}$, at $\mathrm{S} 9$ and $\mathrm{S} 31$, where $P^{*}$ m was invariant with depth and the water column was mixed to 50 and $80 \mathrm{~m}$, respectively, daily production was very low: between 111 and $172 \mathrm{mg} \mathrm{C} \mathrm{m} \mathrm{C}^{-1}$. Further south and close to the ice edge at F6 and S8, ADP was higher, 392 and $484 \mathrm{mg} \mathrm{C} \mathrm{m}^{-2} \mathrm{~d}^{-1}$, while at the single Phaeocystis sp. dominated station (S30) of the MIZ, ADP was $558 \mathrm{mg} \mathrm{C} \mathrm{m}^{-2} \mathrm{~d}^{-1}$.

\section{Regional comparison of size-fractionated chl a data}

Size-fractionated chl a data (Fig. 6) emphasise and correspond with the regional phytoplankton biomass distribution. At the centre of phytoplankton blooms (at S30 within the MIZ and at F11, S20, S21 and S25 within the APF), the $>20 \mu \mathrm{m}$ netplanktonic fraction made up $>60 \%$ of the phytoplankton biomass. At the margins of the Polar Frontal bloom, this fraction made up $50 \%$ of the total, while the $2-20 \mu \mathrm{m}$ nanoplanktonic size class made up $40 \%$ and picoplankton $<2 \mu \mathrm{m}$ contributed the balance. By contrast, in the southern ACC close to the ice edge, the $>20 \mu \mathrm{m}$ fraction contributed only $25 \%$ to the total biomass relative to the $2-20 \mu \mathrm{m}$ fraction contribution of $55 \%$. Within the SAPF and icefree $\mathrm{ACC}$ regions, the $2-20 \mu \mathrm{m}$ fraction contributed $70 \%$ of the biomass. 


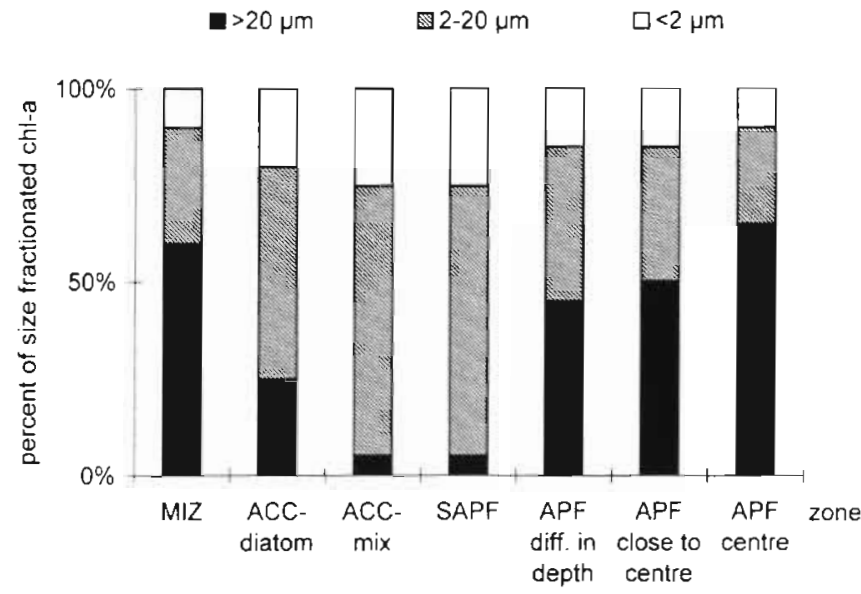

Fig. 6. Size-fractionated $(>20,2-20$ and $<2 \mu m)$ chl a concentrations within the euphotic zone during ANT XIII/2. APF diff. (different) in depth: APF stations where $P_{\mathrm{m}}{ }_{1} \%$ light depth > $P{ }^{\prime}$ surface; ACC-diatom: ACC stations close to the ice edge with a high portion of diatoms in the phytoplankton community; ACC-mix: ACC stations with equal contributions of phytoplankton groups in the community

\section{DISCUSSION}

\section{Methodological considerations}

In our study we were able to resolve differences in photosynthetic characteristics and pigment distribution within the various zones of the Southern Ocean. This was achieved by using a detailed analysis of spectrally weighted $\alpha^{*}$ and $k_{\mathrm{d}}[\mathrm{PAR}]$, and the depth-dependent parameters $B_{\mathrm{c}}, k_{\mathrm{d}}[\mathrm{PAR}], \bar{a}_{\dot{0}}{ }^{\circ}, a_{\dot{\phi}}{ }^{\circ}, \alpha^{*}$ and $P^{*}{ }_{\mathrm{m}}$. We also included in our ADP calculation the integration of photosynthetic rates to the depth where instantaneous net photosynthesis was approximately zero.

By considering the spectral distribution of the light field we obtained precise values for PAR (and $k_{d}$ [PAR]) and for $\alpha^{*}$ by spectral weighting with $\bar{\alpha}_{\phi}$. As shown in experiments by Lewis et al. (1985), $\alpha^{*}$ varies significantly with wavelength due to its linear correlation with the particulate absorption spectrum of phytoplankton. Uncorrected ADP calculations were 59 to $108 \%$ of corrected values when based on $\alpha^{*}$ values which ignored the in vivo underwater light spectrum (Table 4a).

The parameters $B_{c}, a_{\phi}{ }^{*}, \bar{a}_{\phi}{ }^{*}, \alpha^{*}, P^{*}{ }_{m}$ and $k_{\mathrm{q}}$ often show vertical structure within the water column, presumably due to deep chlorophyll maxima, mixing and differing photoacclimational stages. As shown by Bracher \& Tilzer (1998), $a_{\phi}{ }^{*}$ and $k_{\mathrm{d}}$ varied strongly with depth in stabilised water columns during our cruise (e.g. at S30 in the MIZ and in the APF [S13, S20]). Here, light absorption by phytoplankton and light attenuation decreased sharply below the UML since $B_{c}$ was low, and $a_{\phi}{ }^{\circ}$ decreased due to a package effect of the low-light-acclimated cells. By contrast, in a well-mixed water column (e.g, at S31 within the $\mathrm{ACC}, a_{\phi}{ }^{*}$ and $k_{\mathrm{d}}$ values were rather constant. In addition, using instantaneous irradiances for calculations is important, since averaging irradiance for the daylight period results in an overestimate of ADP when the average irradiance greatly exceeds $E_{k}$. Relative to our method, which includes variations in depth and time [regarding $B_{\mathrm{c}}\{z\}, a_{\varphi}^{*}(z), \phi^{*}(z), \alpha^{*}(z)$, $P^{\cdot}{ }_{\mathrm{m}}(z), k_{\mathrm{d}}(z)$ and $\left.E_{\mathrm{d}}[\mathrm{PAR}](z, t)\right]$, methods which average over both (e.g. Talling's [1957] protocol), or one of the two, may lead to significant errors (Table $4 \mathrm{~b}-\mathrm{d}$ ). Averaging over depth and time leads to an overestimate of ADP by $44 \%$ (SD $9 \%$ ). Resolving the parameter of depth only leads to an overestimate of $27 \%$ (SD $12 \%$ ) and resolving time only leads to an underestimate of $51 \%$ (SD 18\%). Under- or overestimating ADP can have significant theoretical consequences. For example, if we derive a growth rate of $0.5 \mathrm{~d}^{-1}$ using ADP values and areal biomass concentration,

Table 4. Comparison of A.DP rates calculated in our study including spectral correction of $\alpha^{\circ}$, resolving the parameters $B_{\mathrm{c}}$, $a_{4}{ }^{*}$, $\bar{a}_{a}{ }^{\prime}, \alpha^{*}, P^{*}{ }_{m}$, and $k_{d}$ for depth and $E_{\mathrm{d}}(z, t)$ for depth and time to different methods in which ADP rates were calculated by (a) using Eq. (6), but not spectrally weighting $\alpha^{\prime}$ (= not corrected); (b) using mean values over the euphotic zone and daily mean values of subsurface downwelling irradiance $\bar{E}_{d}(0)$ according to Talling $(1957)$ : ADP $=\bar{B}_{c} P^{\cdot}{ }_{m} / \hat{k}_{d}[P A R] \cdot\left\{1-\exp \left[\bar{E}_{d}(0) / E_{k}\right]\right\} \cdot 0.9 N ;(c)$ using mean values over the euphotic zone and integrating over time with $E_{d}(0, t)$; and (d) using Eq. (6), but mean values over the euphotic zone for $B_{c}, a_{\phi}{ }^{*}, \bar{a}_{0^{*}}, \alpha^{*}, P^{*}{ }_{m}$, and $k_{d}$. Values given are calculated ADP rates as a percentage of the rates in this study

\begin{tabular}{|ccccc|}
\hline & $(\mathrm{a})$ & $(\mathrm{b})$ & (c) & (d) \\
\hline$\alpha^{*}$ & Not corrected & Corrected & Corrected & Corrected \\
Depth & Resolved & Mean & Resolved & Mean \\
Time & Resolved & Mean & Mean & Resolved \\
n & 22 & 22 & 22 & 22 \\
Min. $-\max$ & $59-108$ & $78-283$ & $113-159$ & 102 \\
Mean & 80 & 144 & 127 & 49 \\
SD & 9 & 43 & 12 & 18 \\
\hline
\end{tabular}


then an overestimate of daily production by $20 \%$ can lead to an error of $270 \%$ in biomass after $10 \mathrm{~d}$.

The problems associated with the estimation of primary production based on $P$ vs $E$ curves have been well documented by Sakshaug et al. (1997). In the near future, some of these problems may be resolved by new techniques, such as the fast-repetition-rate fluorometer (FRRF), or the pulse-amplitude-modulated fluorometer (PAM) (Falkowski \& Kolber 1993, Schreiber et al. 1995). When these techniques, which are fast and non-destructive, are proven to provide robust and direct in situ measures of $\mathrm{P}$ vs $\mathrm{E}$ parameters, productivity and physiological responses to light and nutrient regimes over time and space scales hitherto unknown will become available.

\section{Phytoplankton physiology, biomass and composition in the Southern Ocean}

We encountered significant phytoplankton blooms only at the APF and within the MIZ. The $>20 \mu \mathrm{m}$ size class dominated the biomass at both bloom sites, but while at the bloom within the APF diatoms dominated the algal community, contributing to high ADP and $P \cdot$. values (>730 $\mathrm{mg} \mathrm{C} \mathrm{m}^{-2} \mathrm{~d}^{-1}$ and $>2 \mathrm{mg} \mathrm{C} \mathrm{mg} \mathrm{chl} \mathrm{a}^{-1}$ $\mathrm{h}^{-1}$, respectively); Phaeocystis sp. dominated within the MIZ bloom and ADP and $P^{\circ}$ values were lower (558 $\mathrm{mg} \mathrm{C} \mathrm{m} \mathrm{m}^{-2} \mathrm{~d}^{-1}$ and $<1.3 \mathrm{mg} \mathrm{C} \mathrm{mg} \mathrm{chl} \mathrm{a}^{-1} \mathrm{~h}^{-1}$, respectively). The large, spiny diatoms dominating the bloom at the APF were slow growing, exhibiting a high uptake rate of silicate over a long period, but were nevertheless buoyant (Hense et al. 1998). Export production was therefore low $\left(<100 \mathrm{mg} \mathrm{C} \mathrm{m}^{-2} \mathrm{~d}^{-1}\right.$; Rutgers van der Loeff et al. 1997) and the POC:PON (particulate organic carbon to nitrogen) ratio $(<6.5: 1)$ and phaeophytin:chl a ratio $(<0.22$ at the upper $50 \mathrm{~m})$ indicate that these phytoplankton were in a healthy phase (Hense et al. 1998). By contrast, the MIZ Phaeocystis sp. bloom exhibited a POC:PON ratio of $>20: 1$ at $90 \mathrm{~m}$ depth and an increase in the phaeophytin:chl a ratio to $>0.4: 1$ at $40 \mathrm{~m}$ (Bathmann et al. 1997b). Apart from taxon-specific differences, these ratios are indicative of an aged phytoplankton bloom. In support of this, $\Phi_{m}$ for the MIZ Phaeocystis sp. bloom was low, which Cleveland et al. (1989) interpret as being indicative of a terminal phase. The APF bloom, by contrast, was characterised by a high $\Phi_{\mathrm{m}}$ value [close to the theoretical maximum of $0.094 \mathrm{~mol} \mathrm{C}$ (mol photons) $)^{-1}$ at S20] indicative of an actively growing population.

The ADP rates of phytoplankton at Stns S18 and S6 are of special interest since, despite a relatively low biomass $\left(<0.9\right.$ and $<0.6 \mathrm{mg} \mathrm{chl} a \mathrm{~m}^{-3}$ within the euphotic zone, respectively), the ADP rates were similar to those exhibited by a higher biomass $(>1.5 \mathrm{mg}$ chl $a \mathrm{~m}^{-3}$ ) close to the centre of the APF (Fig. 5). Stn 18 was characterised by an unusually high density of coccolithophorid prymnesiophytes $(>30 \%)$ while at Stn S6, both dinoflagellates and coccolithophorids (20 to $25 \%$ each) contributed to the phytoplankton composition (M. Schültke pers. comm.). We attribute the low biomass of phytoplankton at these 2 stations to the strong grazing pressure exerted by high concentrations of cyclopoid copepods which removed $80 \% \mathrm{~d}^{-1}$ of the phytoplankton standing stock, mainly dinoflagellates and coccolithophorids (Dubischar \& Bathman 1998).

In general, the values of the parameters characterising the P vs E curve and the ADP rates measured in our study are in the range of values measured in other primary production studies performed with phytoplankton of the Southern Ocean (Table 5). The differences between values can be caused either by differences in phytoplankton physiology and biomass influenced by species composition, photoacclimation, time of sampling, and differences in abiotic factors at the various sites or by differences in methods used for obtaining such data (especially regarding the light field during incubation, the incubation time and the calculation of ADP from P vs E data, as pointed out above).

\section{Abiotic controls of phytoplankton distribution, biomass and productivity}

\section{Nutrients}

Overall, macronutrient concentrations exceeded the requirements for phytoplankton growth (Hartmann et al. 1997, Hense et al. 1998), as is generally the case in the Southern Ocean. Among nutrients, surface silicate concentrations varied the most, with concentrations ranging from $80 \mu \mathrm{M}$ at $68^{\circ} \mathrm{S}$ to $0.41 \mu \mathrm{M}$ at the northern edge of the APF, where Si could well have been limiting (Pondaven et al. 1998). By contrast, surface nitrate and phosphate concentrations were largely invariate ( $>18$ and $>1.3 \mu \mathrm{M}$, respectively) throughout the whole sampling area. This observation means that the surface $\mathrm{Si}: \mathrm{NO}_{3}$ ratio shifts, south to north, from $4.4: 1$ to 0.023:1, implying not only potential Si limitation, but uncoupled recycling rates for the 2 nutrients, where Si is exported out of the euphotic zone but $\mathrm{NO}_{3}$ is not or is at least in balance with inputs. Measured low $f$-ratios $(<0.4)$ throughout the region confirm that the utilisation and export of $\mathrm{NO}_{3}$ as PON is indeed low and accounts, in part, for the sustained meridional $\mathrm{NO}_{3}$ concentrations (Lucas et al. 1997) which must nevertheless also be maintained by the upwelling of $\mathrm{NO}_{3}$ rich water. 
Table 5. Comparison of (a) ADP rates and (b) P versus E parameters $\left(P^{*}{ }_{m}, \alpha^{*}\right.$ and $\left.E_{k}\right)$ from the literature and our study. Units of the different parameters are defined in Table 1. Abbrevations for different methods used are defined as follows: PE $=\mathrm{P}$ vs $\mathrm{E}$ curves performed in in vitro incubation (IV); SIS = simulated in situ incubation (on-deck); IS = in situ incubation

\begin{tabular}{|c|c|c|c|c|c|c|}
\hline \multicolumn{2}{|l|}{$\begin{array}{l}\text { (a) ADP rates } \\
\text { Where }\end{array}$} & When & Method & \multicolumn{2}{|l|}{$\mathrm{ADP}$} & Source \\
\hline \multicolumn{2}{|l|}{ Coastal region, Weddell Sea } & Dec-Jan & IS & \multicolumn{2}{|l|}{1400} & El-Sayed \& Mandelli (1965) \\
\hline \multicolumn{2}{|l|}{$61^{\circ} \mathrm{S}, 45^{\circ} \mathrm{W}$} & Summer & IS & \multicolumn{2}{|c|}{$1700-2800$} & Horne et al. (1969) \\
\hline \multicolumn{2}{|l|}{ Bransfield Strait } & Summer & IS & \multicolumn{2}{|c|}{$400-5300$} & El-Sayed $(1970)$ \\
\hline \multicolumn{2}{|l|}{ Gerlache Strait } & Summer & IS & \multicolumn{2}{|c|}{$400-3200$} & El-Sayed (1970) \\
\hline \multicolumn{2}{|l|}{ Bellingshausen Sea } & Summer & IS & \multicolumn{2}{|c|}{$100-700$} & El-Sayed $(1970)$ \\
\hline \multicolumn{2}{|l|}{ Oceanic region, Weddell Sea } & Dec-Jan & IS & \multicolumn{2}{|c|}{$100-300$} & El-Sayed \& Taguchi (1981) \\
\hline \multicolumn{2}{|l|}{ Ross Sea } & Dec-Jan & IS & \multicolumn{2}{|c|}{$200-950$} & El-Sayed et al (1983) \\
\hline \multicolumn{2}{|l|}{$61^{\circ}-63^{\circ} \mathrm{S}, 54^{\circ}-60^{\circ} \mathrm{W}$} & Nov-Dec & SIS & \multicolumn{2}{|c|}{$233-1633$} & von Bodungen et al. (1986) \\
\hline \multicolumn{2}{|l|}{$62^{\circ}-65^{\circ} \mathrm{S}, 60^{\circ}-61^{\circ} \mathrm{W}$} & Winter & PE & $0.5-7$ & & Brightman \& Smith (1989) \\
\hline $62^{\circ}-65^{\circ} \mathrm{S}, 60^{\circ}-61^{\circ} \mathrm{W}$ & & Winter & SIS & $2.7-1$ & & Brightman \& Smith (1989) \\
\hline $46^{\circ}-70^{\circ} \mathrm{S}, 10^{\circ}-50^{\circ} \mathrm{E}$ & & Dec-Mar & SIS & $300-10$ & & Verlencar et al. $(1990)$ \\
\hline Drake Passage-Gerlache & & Dec & IS & $1700-34$ & 400 & Holm-Hansen \& Mitchell (1991) \\
\hline Drake Passage-Gerlache & & Jan & IS & $240-14$ & & Holm-Hansen \& Mitchell (1991) \\
\hline Drake Passage-Gerlache & & Feb & IS & $130-69$ & & Holm-Hansen \& Mitchell (1991) \\
\hline Drake Passage-Gerlache & & Mar & IS & $70-21$ & & Holm-Hansen \& Mitchell (1991) \\
\hline $60^{\circ}-62.5^{\circ} \mathrm{S}, 58^{\circ}-52^{\circ} \mathrm{W}$ & & Jan-Mar & SIS & $170-92$ & & Helbling et al. (1995) \\
\hline $47^{\circ}-60^{\circ} \mathrm{S}, 6^{\circ} \mathrm{W}$ APF & & Oct-Nov & SIS & $800-30$ & & Jochem et al.(1995) \\
\hline $47^{\circ}-60^{\circ} \mathrm{S}, 6^{\circ} \mathrm{W}$ ACC (ice-fr & free) & Oct-Nov & SIS & $170-25$ & & Jochem et al.(1995) \\
\hline $47^{\circ}-60^{\circ} \mathrm{S}, 6^{\circ} \mathrm{WMIZ}$ & & Oct-Nov & SIS & $170-32$ & & Jochem et al.(1995) \\
\hline $65^{\circ}-69^{\circ} \mathrm{S}, 83^{\circ}-88^{\circ} \mathrm{W}$ & & Nov-Dec & $\mathrm{PE}$ & $36-49$ & & Savidge et al. (1995) \\
\hline $65^{\circ} \mathrm{S}, 64^{\circ} \mathrm{W}$ & & $\mathrm{Dec}-\mathrm{Feb}$ & $\mathrm{PE}$, daily cy & $100-69$ & & Moline \& Prezelin (1997) \\
\hline Bransfield-Bellıngshausen & & $\operatorname{Jan}$ & $P E$ & $808-16$ & & Figueiras et al. (1998) \\
\hline Bransfield-Weddell Waters & & $\operatorname{Jan}$ & PE & $513-17$ & & Figueiras et al. (1998) \\
\hline Weddell-Scotia Confluence & & Jan & PE & $179-51$ & & Figueiras et al. (1998) \\
\hline Ice edge & & Jan & $\mathrm{PE}$ & $645-82$ & & Figueiras et al. (1998) \\
\hline $77^{\circ}-72^{\circ} \mathrm{S}, 175^{\circ} \mathrm{E}$ polynya & & Nov-Dec & SIS & $680-11$ & & Saggiomo et al. (1998) \\
\hline $77^{\circ}-72^{\circ} \mathrm{S}, 175^{\circ}$ E MIZ & & Nov-Dec & Sis & $990-270$ & & Saggiomo et al. (1998) \\
\hline $77^{\circ}-72^{\circ} \mathrm{S}, 175^{\circ}$ E pack ice & & Nov-Dec & SIS & $280-60$ & & Saggiomo et al. (1998) \\
\hline $77^{\circ}-72^{\circ} \mathrm{S}, 175^{\circ} \mathrm{E}$ inshore & & Jan-Feb & SIS & $520-12$ & & Saggiomo et al. (1998) \\
\hline APF & & Dec-Jan & PE & $300-93$ & & Our study \\
\hline SAPF & & Dec-Jan & PE & $250-50$ & & Our study \\
\hline $\mathrm{ACC}$ & & Dec-Jan & PE & $120-48$ & & Our study \\
\hline MIZ & & Dec-Jan & PE & 560 & & Our study \\
\hline (b) P vs E parameters & & & & & & \\
\hline Where & When & Method & $P^{\cdot}{ }_{\mathrm{m}}$ & $\alpha^{*}$ & $E_{k}$ & Source \\
\hline $61^{\circ}-63^{\circ} \mathrm{S}, 54^{\circ}-65^{\circ} \mathrm{W}$ & Nov-Dec & $\operatorname{SIS}(6-24 h)$ & $0.41-1.19$ & $0.001-0.011$ & $19-175$ & Tilzer et al. (1985) \\
\hline Scotia/Weddell Sea & Feb-Mar & PE under SIS & $0.8-4.4$ & $0.0094-0.049$ & $160-550$ & Sakshaug \& Holm-Hansen (1986) \\
\hline Scotia/Weddell Sea & Oct-Nov & PE (2 h) & $0.56-2.66$ & $0.0038-0.0110$ & $44-88$ & Tilzer et al. (1986) \\
\hline $78^{\circ} \mathrm{S}, 166^{\circ} \mathrm{W}$ & Sep-Dec & $\mathrm{PE}(4 \mathrm{~h})$ & $0.46-1.8$ & $0.015-0.29$ & $50-80$ & Rivkin \& Putt (1988) \\
\hline $62^{\circ}-65^{\circ} \mathrm{S}, 60^{\circ}-61^{\circ} \mathrm{W}$ & Winter & $P E(2-4 h)$ & $0.5-2.4$ & $0.025 \pm 0.02$ & $37-177$ & Brightman \& Smith $(1989)$ \\
\hline Drake Passage-Gerlache D & Dec-Mar & IS $(8-24 h)$ & 1.1 & 0.06 & 18 & Holm-Hansen \& Mitchell (1991) \\
\hline $60^{\circ} \mathrm{S}-62^{\circ} \mathrm{S}, 54^{\circ}-46^{\circ} \mathrm{W}$ & Dec-Jan & $P E(2-3 h)$ & $1.94 \pm 0.79$ & $0.058 \pm 0.023$ & $35 \pm 13$ & Figueiras et al. (1994) \\
\hline $60^{\circ}-62.5^{\circ} \mathrm{S}, 58^{\circ}-52^{\circ} \mathrm{W}$ & Jan-Mar & $\operatorname{SIS}(6-10 h)$ & $1.02-2.92$ & $0.013-0.029$ & $91-105$ & Helbling et al. (1995) \\
\hline $65^{\circ} \mathrm{S}, 64^{\circ} \mathrm{W}$ & Dec-Feb & PE, daily cycle & $3.66 \pm 1.13$ & $0.36 \pm 0.15$ & $42-114$ & Moline \& Prezelin (1997) \\
\hline $60^{\circ}-62^{\circ} \mathrm{S}, 54^{\circ}-46^{\circ} \mathrm{W}$ & Jan & PE $(2-3 h)$ & $1.42 \pm 0.52$ & $0.018 \pm 0.009$ & $87 \pm 26$ & Figueiras et al. (1998) \\
\hline Bransfield-Bellingshausen & $\operatorname{Jan}$ & $P E(2-3 h)$ & $1.6 \pm 0.42$ & $0.019 \pm 0.004$ & $84 \pm 22$ & Figueiras et al. (1998) \\
\hline Bransfield-Weddell Waters & Jan & $P E(2-3 h)$ & $1.41 \pm 0.36$ & $0.017 \pm 0.008$ & $88 \pm 22$ & Figueiras et al. (1998) \\
\hline Weddell-Scotia Confluence & e Jan & $P E(2-3 h)$ & $1.63 \pm 0.65$ & $0.007 \pm 0.003$ & $100 \pm 42$ & Figueiras et al. (1998) \\
\hline Ice edge & $\operatorname{Jan}$ & $P E(2-3 h)$ & $0.79 \pm 0.52$ & $0.022 \pm 0.012$ & $82 \pm 21$ & Figueiras et al. (1998) \\
\hline $\mathrm{APF}$ & Dec-Jan & $\mathrm{PE}(4 \mathrm{~h})$ & $0.83-3.2$ & $0.006-0.07$ & $60-250$ & Our study \\
\hline SAPF & Dec-Jan & PE ( $4 \mathrm{~h})$ & $0.71-3.2$ & $0.008-0.05$ & $50-180$ & Our study \\
\hline $\mathrm{ACC}$ & Dec-Jan & $\mathrm{PE}(4 \mathrm{~h})$ & $0.27-1.1 .3$ & $0.014-0.034$ & $8-83$ & Our study \\
\hline Miz & Dec-Jan & PE (4h) & $1.06-1.28$ & $0.008-0.014$ & $80-160$ & Our study \\
\hline
\end{tabular}


Among micronutrients, iron concentrations (de Jong et al. 1997) were low (<1 nM) at all sites during the whole cruise and were therefore an unlikely influence on the relative biomass distribution which reached a maximum of only $<2 \mathrm{mg} \mathrm{chl} \mathrm{a} \mathrm{m}^{-3}$. However, during a previous cruise to the APF at $6^{\circ} \mathrm{W}$ in the Atlantic Sector (ANT X/6, de Baar et al. 1995), iron concentrations approached $4 \mathrm{nM}$, concurrent with a higher phytoplankton biomass ( $>4 \mathrm{mg} \mathrm{chl} \mathrm{a} \mathrm{m}^{-3}$ ) dominated by silicified diatoms. It is therefore tempting to speculate that phytoplankton productivity and biomass within the APF during our cruise could have been iron-limited, although the synergistic relationship between iron and light limitation cannot be ignored (Sunda \& Huntsman 1997), particularly with regard to diatom dominated new production.

Influence of sampling time in the day

Rivkin \& Putt (1988) suggested that the diurnal cycle of parameters determining the P vs E curve is not as strongly developed in the Southern Ocean as in temperate seas. In their study of diel periodicity of photosynthesis in the Southern Ocean, no photoinhibition or pigment responses to the diurnal light regime were detected within a day. In the early austral summer: at the same time of the year as our study, the diurnal differences in $P^{*}{ }_{\mathrm{m}}$ and $\alpha^{*}$ values were small, probably due to the long daylight period (16 to $24 \mathrm{~h}$ ) (Rivkin \& Putt 1988). Although the stations in our study were sampled at different times of the day, we conclude that the observed regional variances in $P^{\cdot}{ }_{\mathrm{m}}$ and $\alpha^{*}$ are unlikely to be due to diurnal responses.

\section{Hydrography}

It is well known that the depth of the UML, its associated vertical stability and the underwater light field are related and fundamentally influence phytoplankton productivity (Sverdrup 1953, Nelson \& Smith 1991). In a vertical light gradient, the tendency for phytoplankton to adjust their photosynthetic characteristics to the local light level at different depths is, however, opposed by the tendency for turbulence to erode this differentiation and bring the phytoplankton community to a physiologically homogenous state over depth (Lewis et al. 1984). It is this which underpins the 'critical depth' concept first quantified by Sverdrup (1953) and reconsidered in the Southern Ocean context by Nelson \& Smith (1991). By this reasoning, productivity over most of the Southern Ocean is low, even in summer, because the depth of the surface mixed layer $\left(Z_{\mathrm{m}}\right)$ approaches or exceeds the Sverdrup critical depth $\left(Z_{c \mathrm{r}}\right)$, which is a function of the solar irradiance at the sea surface and the water clarity. Strongly stratified regions in the Southern Ocean have been identified mainly in the MIZ and around land masses, where glacial meltwater or rainwater run-off provide a buoyancy input into the surface layer (Marra \& Boardman 1984, Smith \& Nelson 1985, Perissinotto et al. 1990 , 1992, Mitchell \& Holm-Hansen 1991). However, the paradigm of meltwater-induced stability as the principal mechanism accounting for regions of higher productivity is no longer universal. For example, during the STERNA cruise to the Bellingshausen Sea, elevated productivity in the MIZ was associated primarily with the presence of a strong frontal jet (the Southern Polar Front) rather than to ice melt and retreat (Pollard et al. 1995, Waldron et al. 1995). Sloping isopycnals at frontal edges in areas of high stability can therefore also result in shallower stratification and elevated productivity (Lutjeharms et al. 1985, Pollard et al. 1995). But can this argument be extended to the APF during our study?

Based on a change of sigma-t of $>0.05$ over a $10 \mathrm{~m}$ depth interval, UML depths in our study were shallow within the MIZ $(12 \mathrm{~m})$ and within the APF (15 to $35 \mathrm{~m})$. Chlorophyll concentrations and ADP rates were maximal at the northern edge of the APF where silicate was close to denletion Laubscher et al (1993) also noted that the northern edge of the APF at $10^{\circ} \mathrm{E}$ in the austral summer was characterised by very shallow UML depths $(<20 \mathrm{~m})$ where surface and integrated silicate concentrations were probably low enough to limit diatom growth. In their study, the densest blooms were found in the core of the front, where high vertical stability occurred in conjunction with high silicate concentrations.

Strong temperature gradients are a typical feature of the fronts encountered in the Southern Ocean (Pollard et al. 1995). It is likely that they too play a significant role in bloom dynamics in our study within the APF. In agreement with Laubscher et al. (1993), we also noted maximum chl a concentrations and ADP rates on the warmer side of the front $1>4^{\circ} \mathrm{C}$ surface water). Apart from temperature-dependent stability considerations, temperature itself strongly influences phytoplankton production in the Southern Ocean (Jacques 1983, Tilzer et al. 1985, 1986, Palmisano et al. 1987, Tilzer \& Dubinsky 1987). Jacques (1983) demonstrated that warmer temperatures could have a positive, but limited, effect on growth rates of Antarctic algae and that the response is also species specific. In summary, Jacques (1989) has suggested that Antarctic algae are somewhat constrained by low temperatures, based on the assumption that the enzymatic composition and control of carbon fixation is similar in all algal species. 
Taken collectively, vertical mixing processes and water column stratification in combination with silicate concentrations and temperature seem to be the main factors driving production and growth of phytoplankton during this study. The abundance of macronutrients did not play an important role in determining phytoplankton biomass and production, although the question of potential iron limitation, particularly for diatoms, was not resolved by this study.

Acknowledgements. The authors would like to thank C. Bratrich, R. Lehmann, the crew and the captain of RV 'Polarstern' and chief scientist $V$. Smetacek for their support during ANT $X I I / 2$. Special thanks go to R. Lehmann for her assistance in creating P vs E curves. We also thank I. Ewen and I. Hense for chlorophyll analysis, I. Zondervan for DIC analyses and U. Hoge for technical help with the MER. This research was supported by the Alfred Wegener Institute (AWI) for Polar and Marine Research and generous 'visiting scientist' funding to M.I.L. from the AWI and from the George Deacon Division, SOC, UK. This is AWI contribution number 1651

\section{LITERATURE CITED}

Arrigo KR, Worthen D, Schnell A, Lizotte MP (1998) Primary production in Southern Ocean Waters. J Geophys Res 103: $15587-15600$

Arrigo KR, Robinson DH, Worthen DL, Dunbar RB, DiTullio GR, VanWoert M, Lizotte MP (1999) Phytoplankton community structure and the drawdown of nutrients and $\mathrm{CO}_{2}$ in the Southern Ocean. Science 283:364-366

Atlas D, Bannister TT (1980) Dependence of mean spectral extinction coefficient of phytoplankton on depth, water color and species. Limnol Oceanogr 25:157-159

Bannister TT (1974) Production equations in terms of chlorophyll concentration, quantum yield, and upper limit production. Limnol Oceanogr 19:1-12

Bathmann UV, Scharek R, Klaas C, Dubischar CD. Smetacek $\mathrm{V}$ (1997a) Spring development of phytoplankton biomass and composition in major water masses of the Atlantic sector of the Southern Ocean. Deep-Sea Res II 44:51-67

Bathmann U, Hense I, Nacken M, Reynarson T (1997b) Pigment concentrations. Rep Polar Res 221:72-77

Bathmann U, Priddle J, Trégeur P, Lucas MI, Parslow J, Hall J (1998) Plankton ecology and biogeochemistry in the Southern Ocean: a first review of Southern Ocean JGOFS. In: Ducklow H, Field JG, Platt I (eds) First JGOFS International Scientific Symposium, Villefranche, France, May $8-12$, 1995. IGBP Series, Cambridge University Press, Cambridge, p 39-56

Bidigare RR, Prezelin BB, Smith RC (1992) Bio-optical models and the problem of scaling. In: Falkowski PG, Woodhead AD (eds) Primary productivity and biogeochemical cycling in the sea. Plenum Press, New York, p 175-212

Bracher AU, Tilzer MM (1998) Underwater light field and phytoplankton absorbance in the Southern Ocean during early summer 1995/1996. EOS (Trans Am Geophys Union) 79:181

Bricaud A, Stramski D (1990) Spectral absorption coefficients of living phytoplankton and nonalgal biogenous matter: a comparison between the Peru upwelling area and the Sargasso Sea. Limnol Oceanogr 35:562-582

Brightman RI, Smith WO (1989) Photosynthesis-irradiance relationships of Antarctic phytoplankton during austral winter. Mar Ecol Prog Ser 53:143-151

Carmack EC (1977) Water characteristics of the Southern Ocean south of the Polar Front. In: Angel M (ed) A voyage of discovery. Pergamon Press, Oxford, p 7-19

Chisholm SW, Morel FMM (1991) What controls phytoplankton productivity in nutrient-rich areas of the open sea? Limnol Oceanogr 36:1507-1970

Cleveland JS, Perry MJ, Kiefer DA, Talbot MC (1989) Maximal quantum yield of photosynthesis in northwestern Sargasso Sea. J Mar Res 47:869-886

Comiso JC, Maynard NG, Smith WO, Sullivan CW (1990) Satellite ocean colour studies of Antarctic ice edges in the summer/autumn. J Geophys Res 95:9481-9496

Dafner EV, Mordasova NV (1994) Influence of biotic factors on the hydrochemical structure of surface water in the Polar Frontal Zone of the Atlantic Antarctic. Mar Chem 45 $137-148$

de Baar HJW, de Jong JTM, Bakker DCE, Löscher BM, Veth C. Bathmann U, Smetacek V (1995) Importance of iron for plankton blooms and carbon dioxide drawdown in the Southern Ocean. Nature 373:412-415

de Jong JTM, den Das J, Timmermans KR, de Baar HJW (1997) Field distribution of iron in a section of the Antarctic Polar Frontal Zone. Rep Polar Res 221:53-61

DeMaster DJ (1981) The supply and accumulation of silica in the marine environment. Geochim Cosmochim Acta 45: $1715-1732$

DeMaster DJ, Nelson TM, Harden SL, Nittrouer CA (1991) The cycling and accumulation of biogenic silica and organic carbon in Antarctic deep-sea and continental margin environments. Mar Chem 35:489-502

Dubischar CD, Bathmann UV (1998) Small sized mesozooplankton in pelagic systems of the polar frontal region in the Southern Ocean. EOS (Trans Am Geophys Union) 79 : 89

El-Sayed SZ (1970) On productivity of the Southern Ocean (Atlantic and Pacific sectors). In: Holdgate MW (ed) Antarctic ecology. Pergamon Press, New York, p 119-135

El-Sayed SZ (1984) Productivity of the Antarctic waters-a reappraisal. In: Holm-Hansen $O$, Bolis L, Gilles $R$ \{eds\} Marine phytoplankton and productivity. Springer-Verlag, New York, p 19-34

El-Sayed SZ (1987) Biological production of Antarctic waters: present paradoxes and emerging paradigms. In: El-Sayed SZ, Tomo AP (eds) Antarctic aquatic biology. SCAR, Cambridge, $p$ 1-21

El-Sayed SZ, Mandelli EF (1965) Primary production and standing crop of phytoplankton in the Weddell Sea and Drake Passage. In: Llano GA (ed) Biology of Antarctic Seas II. Antarct Res Ser 5:87-124

El-Sayed SZ, Taguchi S (1981) Primary production and standing crop of phytoplankton along the ice edge in the Weddell Sea. Deep-Sea Res 28:1017-1032

EI-Sayed SZ, Biggs DC, Holm-Hansen O (1983) Phytoplankton standing crop, primary productivity, and near-surface nitrogenous nutrient fields in the Ross Sea, Antarctica. Deep-Sea Res 30:871-886

Evans CA, O'Reilly JE, Thomas JP (1987) A handbook for the measurement of chlorophyll a and primary production. In: Biological investigations of marine antarctic systems and stocks (biomass), Vol 8. Texas A \& M University, College Station, TX, p 47-107

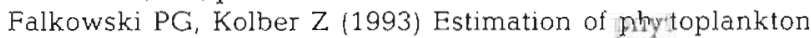
photosynthesis by active fluorescence. ICES Mar Sci Symp 197:92-103

Falkowski PG, Owens TG (1980) Light-shade adaptation: 
two strategies in marine phytoplankton. Plant Physiol 66: 592-595

Figuerias FG, Perez FF, Pazos Y, Rios AF (1994) Light and productivity of Antarctic phytoplankton during austral summer in an ice edge region in the Weddell-Scotia Sea. J Plankton Res 16:233-253

Figueiras FG, Estrada M, Lopez O, Arbones B (1998) Photosynthetic parameters and primary production in the Bransfield Strait: relationships with mesoscale hydrodynamic structures. J Mar Syst 17:129-141

Gran HH (1931) On the conditions for the production of plankton in the sea. Rapp Proc Verb Cons Perm Explor Mer 75:37-46

Hart TJ (1934) On the phytoplankton of the south-west Atlantic and the Bellinghausen Sea, 1929-1931. 'Discovery' Rep 8:1-268

Hartmann C, Hollmann B, Kattner G, Richter KU, Terbrüggen A (1997) Nutrients, dissolved and particulate matter Rep Polar Res 221:44-53

Helbling EW, Villafañe VE, Holm-Hansen O (1995) Variability of phytoplankton distribution and primary production around Elephant Island, Antarctica, during 1990-1993. Polar Biol 15:232-246

Hense I, Bathmann U, Hartmann C (1998) Spiny phytoplankton-slowing down the carbon pump in the Southern Ocean? EOS (Trans Am Geophys Union) 79:89

Holm-Hansen O, Mitchell BG (1991) Spatial and temporal distribution of phytoplankton and primary production in the western Bransfield Strait region. Deep-Sea Res 38: 961-980

Holm-Hansen O, El-Sayed SZ, Frances-Chini GA, Cuhel RL (1977) Primary production and the factors controlling phytoplankton growth in the Southern Ocean. In: Llano GA (ed) Adaptations within the Antarctic ecosystem. Proceedings of the 3rd SCAR Symposium on Antarctic Biology. Gulf Publishing Co, Houston, p 11-50

Horne AJ, Fogg GE, Eagle DJ (1969) Studies in situ of the primary production of an area inshore Antarctic Sea. J Mar Biol Assoc UK 49:393-405

Jacques G (1983) Some ecophysiological aspects of the Antarctic phytoplankton. Polar Biol 2:27-33

Jacques G (1989) Primary production in the Antarctic Ocean during the austral summer. A review. Vie Milieu 39:1-17

Jochem FR, Mathot S, Queguiner B (1995) Size-fractionated primary production in the open Southern Ocean in austral spring. Polar Biol 15:381-392

Karsten U, Garcia-Pichel F (1996) Carotenoids and myco sporine-like amino acid compounds in members of the genus Microcoleus (cyanobacteria): a chemosystematic study. Syst Appl Microbiol 19:285-294

Laubscher RK, Perrissinotto R, MCQuaid CD (1993) Phytoplankton production and biomass at frontal zones in the Atlantic sector of the Southern Ocean. Polar Biol 13: $471-481$

Letelier RM, Bidigare RR, Hebel DV, Ondrusek M, Winn CD, Karl DM (1993) Temporal variability of phytoplankton community structure based on community structure. Limnol Oceanogr 38:1420-1437

Lewis MR, Cullen JJ, Platt I (1984) Relationships between vertical mixing and photoadaptation of phytoplankton: similarity criteria. Mar Ecol Prog Ser 15:141-149

Lewis MR, Warnock RE, Platt T (1985) Absorption and photosynthetic action spectra for natural phytoplankton populations: implications for production in the open ocean. Limnol Oceanogr 30:794-806

Lucas MI, Bury S, Tremblay JE, Bracher A, Lehmann R, Bratrich C, Ewen I (1997) Primary production, nitrogen cycling and photosynthesis-irradiance relationships for phytoplankton associated with the Antarctic Polar Front in summer. Rep Polar Res 221:78-101

Lutjeharms JRE, Walters NM, Allanson BR (1985) Oceanic frontal systems and biological enhancement. Siegfried WR, Condy PR, Laws RM (eds) Antarctic nutrients cycles and food webs. Springer-Verlag, Heidelberg, p 11-21

Marra J, Boardman DC (1984) Late winter chlorophyll a distribution in the Weddell Sea. Mar Ecol Prog Ser 1.9: $197-205$

Michaels AF, Silver MW (1988) Primary production, sinking fluxes and the microbial food web. Deep-Sea Res 35: 473-490

Mitchell BG, Holm-Hansen O (1991) Observations and mod. eling of the Antarctic phytoplankton crop in relation to mixing depth. Deep-Sea Res 38:981-1007

Mitchell BG, Kiefer DA (1988) Chlorophyll a specific absorption and fluorescence excitation spectra for light-limited phytoplankton. Deep-Sea Res 35:639-663

Moline MA, Prezelin BB (1997) High-resolution time-senes data for 1991/1992 primary production and related parameters at a Palmer LTER coastal site: implications for modeling carbon fixation in the Southern Ocean. Polar Biol 17:39-53

Mortlock RA, Charles CD, Froelich PN, Zibello MA, Saltzman J, Hays JD, Burkle LH (1991) Evidence for lower productivity in the Antarctic Ocean during last glaciation. Nature 351:220-223

Nelson DM, Smith WO (1991) Sverdrup revisited: critical depths, maximum chlorophyll levels, and the control of Southern Ocean productivity by the irradiance-mixing regime. Limnol Oceanogr 36:1650-1661

Neori A, Holm-Hansen O, Mitchell BG, Kiefer DA (1984) Photoadaptation in marine phytoplankton. Plant Physiol 76:518-524

Orsi AH, Whitworth T III, Nowlin WD Jr (1995) On the meridional extent and fronts of the Antarctic circumpolar current. Deep-Sea Res 42:641-673

Palmisano AC, SooHoo JB, Moe RM, Sullivan CW (1987) Sea ice microbial communities. VII. Changes in under-ice spectral irradiance during the development of Antarctic sea ice microalgal communities. Mar Ecol Prog Ser 35: $165-173$

Peeken I (1997) Photosynthetic fingerprints as indicators of phytoplankton biomass and development in different water masses of the Southern Ocean during austral spring. Deep-Sea Res II 44:261-282

Perissinotto R, Duncombe Rae CM, Boden BP, Allanson BR (1990) Vertical stability as a controlling factor of the marine phytoplankton production at the Prince Edward Archipelago (Southern Ocean). Mar Ecol Prog Ser 60: 205-209

Perissinotto R, Laubscher RK, McQuaid CD (1992) Marine productivity enhancement around Bouvet and South Sandwich Islands (Southern Ocean). Mar Ecol Prog Ser 88:41-53

Perry MJ, Talbot MC, Alberte RS (1981) Photoadaptation in marine phytoplankton: response of the photosynthetic unit. Mar Biol 62:91-101

Platt T, Harrison WG, Irwin B, Horne EP, Gallegos CL (1982) Photosynthesis and photoadaptation of marine phytoplankton in the Arctic. Deep-Sea Res 29:1159-1170

Pollard RT, Read JF, Allen JT, Griffiths G, Morrison AI (1995) On the physical structure of a front in the Bellinghausen Sea. Deep-Sea Res II 42:955-982

Pondaven P, Fravalo C, Ruiz-Pino D, Treguer P, Queguiner B, Jeandel C (1998) Modelling the silica pump in the perma- 
nently open ocean zone of the Southern Ocean. J Mar Syst $17: 587-619$

Prezelin BB, Sweeney BM (1979) Photoadaptation of photosynthesis in two bloom-forming dinoflagellates. In: Taylor D, Seliger HH (eds) Second International Conference on toxic dinoflagellate blooms. Elsevier, Amsterdam, p $101-106$

Rivkin RB, Putt M (1988) Seasonal pattern of diel periodicity in photosynthesis by polar phytoplankton: species-specific responses. J Phycol 24:369-376

Rutgers van der Loeff MM, Bathmann UV, Buesseler KO (1997) Export production measured with the natural tracer Th-234 and sediment traps. Rep Polar Res 221:113-115

Saggiomo V, Carrada GC, Mangoni O, Ribera d'Alcala M, Russo A (1998) Spatial and temporal variability of sizefractionated biomass and primary production in the Ross Sea (Antarctica) during austral spring and summer. J Mar Syst $17: 115-127$

Sakshaug E, Holm-Hansen O (1984) Factors governing production in polar oceans. In: Holm-Hansen O, Bolis L, Gilles R (eds) Marine phytoplankton and productivity. Springer-Verlag, New York, p 1-18

Sakshaug E, Holm-Hansen $O$ (1986) Photoadaptation in Antarctic phytoplankton: variations in growth rate, chemical composition and $P$ versus I curves. J Plankton Res 8: $459-473$

Sakshaug E, Slagstad D (1991) Light and productivity of phytoplankton in polar marine ecosystems. Polar Res 10: $69-85$

Sakshaug E, Bricaud A, Dandonneau Y, Falkowski PG, Kiefer DA, Legendre L, Morel A, Parslow J, Takahashi M (1997) Parameters of photosynthesis: definitions, theory and interpretation of results. J Plankton Res 19:1637-1670

Savidge G, Harbour D, Gilpin LC, Boyd PW (1995) Phytoplankton distribution and production in the Bellingshausen Sea, austral spring 1992. Deep-Sea Res II 42: $1201-1224$

Schreiber U, Hormann H, Neubauer C, Klughammer C (1995) Assessment of photosystem II photochemical quantum yield by chlorophyll fluorescence quenching analysis. Aust J Plant Physiol 22:209-220

Smetacek VS (1985) Role of sinking in diatom life-history cycles: ecological, evolutionary and geological significance. Mar Biol 84:239-251

Smith RC, Baker KS (1978) Optical classification of natural waters. Limnol Oceanogr 23:260-267

Smith WO, Nelson DM (1985) Phytoplankton bloom produced by a receding ice edge in the Ross Sea: spatial coherence with a density field. Science 227:163-166

Smith WO, Nelson DM (1986) The importance of ice-edge blooms in the Southern Ocean. BioScience 36:251-257

Editorial responsibility: Graham Savidge (Contributing Editor), Portaferry, Northern Ireland, UK
Stoll M, Zondervan I, de Jong E (1997) The carbon dioxide system in Antarctic waters. Rep Polar Res 221:64-67

Strass V, Timmermann R, Fischer H, Hofmann M, Gwilliam P, Wischmeyer A (1997) CTD stations and water bottle sampling. Rep Polar Res 221:34-39

Strickland JDH, Parsons TR (1972) A practical handbook of seawater analysis. Bull Fish Res Bd Can 167

Sullivan CW, Arrigo KR, MCClain CR, Comiso JC, Firestone J (1993) Distributions of phytoplankton blooms in the Southern Ocean. Science 262:1832-1837

Sunda WG, Huntsman SA (1997) Interrelated influence of iron, light and cell size on marine phytoplankton growth. Nature 390:389-392

Sverdrup HU (1953) On conditions for the vernal blooming of phytoplankton. J Cons Int Explor Mer 18:287-295

Talling JF (1957) Photosynthetic characteristics of some freshwater plankton diatoms in relation to underwater radiation. New Phytol 56:29-50

Tilzer MM, Dubinsky Z (1987) Effects of temperature and day length on the mass balance of Antarctic phytoplankton. Polar Biol 7:35-42

Tilzer MM, von Bodungen B, Smetacek V (1985) Lightdependence of phytoplankton photosynthesis on the Antarctic Ocean: implications for regulating productivity. In: Siegfried WR, Condy PR, Laws RM (eds) Antarctic nutrient cycles and food webs. Springer-Verlag. Heidelberg, $p$ 60-69

Tilzer MM, Elbrächter M, Gieskes WW, Beese B (1986) Lighttemperature interactions in the control of photosynthesis in Antarctic phytoplankton. Polar Biol 5:105-111

Tréguer P. Jacques G (1992) Dynamics of nutrients and phytoplankton, and fluxes of carbon, nitrogen and silicon in the Antarctic Ocean. Polar Biol 12:149-162

van Franeker JA, van den Brink NW (1997) Sea ice report. Rep Polar Res 221:122-130

Verlencar XN, Somasunder K, Qasim SZ (1990) Regeneration of nutrients and biological productivity in Antarctic waters. Mar Ecol Prog Ser 61:41-59

von Bodungen B, Smetacek VS, Tilzer MM, Zeitzschel B (1986) Primary production and sedimentation during spring in the Antarctic Peninsula region. Deep-Sea Res 33:177-194

Waldron $H$, Attwood CG, Probyn TA, Lucas MI (1995) Nitrogen dynamics in the Bellingshausen Sea during the austral spring of 1992. Deep-Sea Res II 42:1253-1276

Webb WL, Newton M, Starr D (1974) Carbon dioxide exchange of Alnus rubra: a mathematical model. Ecologia $17: 281-291$

Yentsch CS (1962) Measurements of visible light absorption by particulate matter in the ocean. Limnol Oceanogr 7 : $207-217$

Submitted: May 25, 1998; Accepted: June 22, 1999 Proofs received from author(s): November 16, 1999 